\title{
Progress Under the Uniform Child Custody Jurisdiction Act and Remaining Problems: Punitive Decrees, Joint Custody, and Excessive Modifications
}

\author{
Brigitte M. Bodenheimer ${ }^{\dagger}$
}

The Uniform Child Custody Jurisdiction Act, adopted by eighteen states, facilitates the solution of many of the interstate problems of child custody litigation by introducing greater predictability into the enforcement of out-of-state decrees. There remain some difficult areas requiring attention. In this Article, the author discusses problems of interpretation of the Act and explores three areas of acute difficulty-punitive decrees, joint custody, and excessively modified custody decrees.

When Professor Barbara Armstrong wrote her important work on California family law in the early 1950's, child custody litigation between geographically separated parents was still relatively rare. ${ }^{1}$ The last suppleinent to her treatise, published in 1966, reflects a substantial increase in interstate custody disputes, including child stealings by parents. $^{2}$ In the interim, the growing mobihty of the population and the rising incidence of family disintegration had profoundly influenced child custody law. Professor Armstrong felt a deep concern for the children involved in such contests. Her solicitude surfaces in some rare personal remarks in an otherwise objective presentation of the law. She applauded one court's "emphasis upon the child's right to a stable home" 3 and asserted that "the well-being of the child rather than the punishment or reward of the parent" ought to guide every custody case, whether interstate or domestic. ${ }^{4}$ These wise insights, although seemingly self-evident, are still awaiting their full realization. Indeed, many of the problems discussed im this Article revolve around Professor Armstrong's two concerns.

$\dagger$ Professor of Law, University of California, Davis.

1. Professor Armstrong's chapter on child custody refers to only a few isolated instances of such litigation. 2 B. Armstrong, California Family Law 965, 1018, 1058 (1953) [hereinafter cited as 2 ARMSTRong].

2. See id. at 308, 317-21, 324-28, 335, 338, 349, $359-62$ (Supp. 1966).

3. Id. at 306 .

4. Id. at 326 . 
The number of custody disputes between geographically separated parents has continued to grow enormously in the last decade. Because child custody decrees rendered by one state have traditionally not been considered fimal by the courts of other states, custody can often be relitigated by losing parents who find a receptive forum. ${ }^{5}$ Any domestic divorce involvimg children is thus "a potential interstate nightmare." 6 One million children become exposed to this potential nightmare each year through their parents' divorces. ${ }^{7}$

Increasingly, legal practitioners are faced with the intricate legal and emotional problems of clients growing out of interstate custody disputes: children not returned after out-of-state visits; conflicting custody awards in two states; child abductions and concealments by fugitive parents; and denials of visitation rights in a distant state. ${ }^{8}$ Many parents have becoine impatient with the solutions lawyers can offer. They are demanding better answers than the law now provides. They are taking their concerns to the media, ${ }^{9}$ and citizens' groups have sprung up ${ }^{10}$ to urge action by Congress, state legislatures, and law enforcement officials. Many parents take the law into their own hands or enlist the services of professional child snatchers. ${ }^{11}$ According to one recent estimate, 100,000 children are abducted or detained by parents or their agents every year. ${ }^{12}$ Violence and even death have become a part of the growing ferocity in the battle over children. ${ }^{13}$

5. See text accompanying notes $19-25$ infra.

6. R. Cramton, D. Currie, \& H. Kay, Conflict of Laws 840 (2d ed. 1975) [hereinafter cited as Cramton, CURRIE \& KAY].

7. In 1974 there were 977,000 divorces in the United States, with 1.12 children per divorce. In 1975 divorces had risen to 1,026,000. U.S. BUREAU OF THE CENSUS, Dep'T of Commerce, Statistical AbSTRACT of the United StaTes 68 (1976).

8. See, e.g., Smith v. Evans, Civ. No. 75-8075-9 (Cir. Ct. Pinellas County, Fla. Dec. 5, 1975) (After nine summer visits of three children with the noncustodial father in Florida, the children were not returned to their mother in Nevada the tenth year, and the father obtained custody in Florida.)

9. See, e.g., Smith, Kidnapping with Impunity, L.A. Times, April 19, 1976, at 1; Smith, In Search of Jolie: A Paper Chase, L.A. Times, April 20, 1976, at 1.

10. E.g., Association for Parents' Rights (Sacramento, California); Children's Rights, Inc. (Washington, D.C.); Citizen's Committee to Amend Title 18, Section 1201a of the United States Code (Newhall, California); Fathers Demanding Equal Justice (Los Angeles, California); United Parents of Absconded Children (Cuba, New York).

11. See, e.g., Huey, To Man Whose Job is Child Snatching, End Justifies Means, Wall St. J., Mar. 24, 1976, at 1, col. 4 (Pacific coast ed.). Kidnapping of children by parents and their agents is not a criminal offense under federal law and the law of some states. See Comment, Legalized Kidnapping of Children by their Parents, 80 Dick. L. Rev. 305, 306-09 (1976). But see Cal. Penal Code $§ 278.5$ (West Supp. 1977).

12. See 123 Cong. Rec. H54 (daily ed. Jan. 4, 1977) (remarks of Rep. Moss).

13. See Kidnappings: $A$ Family Affair, NewSweEx, Oct. 18, 1976, at 24 (father and child were killed in father's kidnapping attempt). 
In response to this crisis, eighteen states have adopted the Uniform Cliild Custody Jurisdiction Act. ${ }^{14}$ California has also provided public locating services to find abducted children who are being concealed. ${ }^{15}$ Congress is considering a bill which would complement the Uniform Act by requiring the states to grant full faith and credit to custody decrees. ${ }^{16}$ In addition, crimmal kidnapping laws are being tightened. ${ }^{17}$

Where the Uniforn Act las been adopted, it is beginning to resolve many of the difficulties caused by interstate custody disputes. Certain practices of local courts, however, prevent transstate solutions from being fully effective. For example, some state trial courts overturn their own custody decisions so frequently that it is difficult for the courts of other states to accord the latest local judgment the degree of respect necessary for a well-functioning interstate enforcement system. ${ }^{18}$ Many local courts have reinained state or cominunity oriented

14. See Alaska Stat. $\$ 25.30$ (1977); Cal. Ctv. Code $\$ \S 5150-5174$ (West Supp. 1977); Colo. Rev. StaT. $\$ \S 1413-101$ to 126 (1973); DeL. CoDE tit. 13, §§ 1901-1925 (Supp. 1976); Haw. Rev. Stat. $\$$ 583-1 to 26 (Supp. 1975); Md. ANN. CodE, art. 16, §§ 184-207 (Supp. 1976); 1977 Mont. Laws ch. 537; Mich. CoMP. LAws ANN. $\S \S 600.651-.673$ (Supp. 1976); 1977 Minn. Laws. eh. 8; N.D. CENT. Code \$\$ 14-14-1 to 26 (1971); OR. Rev. STAT. §§ 109.700-.930 (1975); WIS. STAT. ANN. §§ 822.01-.25 (West 1977); WYo. STAT. $\$ \$ 20-143$ to 167 (Supp. 1975). The most recent enactments include Indiana (see 3 FAM. L. REP. (BNA) 2511 (1977)); Iowa (see 3 FAM. L. REP. (BNA) 2478 (1977)); New York (see 3 FAM. L. Rep. (BNA) 2640 (1977)); Pennsylvania (see 3 FAM. L. REP. (BNA) 2582 (1977)); Ohio (see 3 FAM. L. REP. (BNA) 2606 (1977) [signed into law July 26, 1977]).

Even before the Minnesota Legislature enacted the law, the Supreme Court of Minnesota had adopted the Uniform Act as a matter of judicial policy. Petition of Giblin, 232 N.W.2d 214 (Minn. 1975);- Kentucky has enacted the jurisdictional provisions of the Act. KY. REv. STat. $\$ 403.260$ (Supp. 1976). Although the Texas Family Code does not incorporate the exact language of the Uniform Act, it contains provisions that will accomplish some of the Act's major objectives in a different manner. Tex. Fam. Code AnN. $\$ 14.10$ (Vernon Supp. 1976). See Smith, Commentary on Texas Family Code: Parent and Child, 8 TEx. TECH L. Rev. 19, 88-91 (1976); Comment, The Jurisdiction of Texas Courts in Interstate Child Custody Disputes: A Functional Approach, 54 Texas L. REv. 1008, 1038-45 (1976).

A number of decisions in states that have not adopted the Uniform Act evidence some imfluence by the Act. See, e.g., Jolly v. Avery, 220 Kan. 694, 556 P.2d 449 (1976); State ex rel. King, 310 So. 2d 614 (La. 1975); Muirhead v. District Court, 550 P.2d 1304 (Mont. 1976); cf. O'Malley v. O'Malley, 338 A.2d 149 (Me. 1975) (full faith and credit given to a Connecticut decree); Susanne U.N.N. v. Rudolf 0.O., 393 N.Y.S. 2d 472 (App. Div. 1977) (sister state decree enforced absent extraordinary change in circumstances); Cox v. Paulsen, 534 P.2d 14 (Okla. Ct. App. 1975) (court declined jurisdiction to review a California decree).

15. Cal. Welf. \& INST. Code $\$ \$ 11478,11478.5$ (West Supp. 1977).

16. H.R. 988, 95th Cong., 1st Sess. (1977). See notes 141-143 infra and accom: panying text.

17. See, e.g., CaL. Pennl Code $\S \S 278,278.5$ (West Supp. 1977). Proposed federal kidnapping legislation is discussed in the text accompanying note 144 infra.

18. Frequent changes also diminish the parents' respect for judicial determinations and above all disregard "the child's right to a stable home." 2 ARMSTRONG, stipra note 1, at 306 (Supp. 1966). 
despite the upsurge in population mobility which has resulted in many divorced parents living in distant localities. These courts do not yet perceive themselves as links in an interstate - and often internationalnetwork of courts compelled to work together to disentangle the coinplex lives of children with geographically separated parents. Once interstate recognition and enforcement of custody decrees has become the prevailing norm, it will be even more essential for state trial courts to be aware of the effects of their custody decrees on the outside world as well as in the local community. Until such a reorientation is achieved in the local trial courts, certain adjustments in the interstate recognition scheme are necessary to deal with the problen.

This Article first briefly describes traditional interstate custody law and the changes effected by the Uniform Child Custody Jurisdiction Act. Part II then explains how the Uniform Act is operating in practice and discusses problems in its interpretation. Supplementary state and federal legislation is examined in Part III. Finally, the Article concentrates on the interstate problems created by three local judicial practices: punitive custody changes, joint custody decrees, and excessive modifications of custody judgnients.

\section{I}

\section{Traditional LaW and Solutions Offered by the UNIFORM CHILD CUSTODY JURISDICTION ACT}

\section{A. The Traditional Law}

Child custody conflicts law was developed by judicial decisions of the individual states without the benefit of the full faith and credit clause $^{19}$ or guidance from the United States Supreme Court. On the contrary, the Court gave the states carte blanche "to disregard the [custody] judgnient [of another state], to qualify it, or to depart frons it as does the State where it was rendered."20 The resulting law is, as many coninientators have benioaned, uncertain and unpredictable. ${ }^{21}$

19. U.S. CoNST. art. IV, $\S 1$.

20. New York ex rel. Halvey v. Halvey, 330 U.S. 610, 615 (1947). See also Ford v. Ford, 371 U.S. I87 (1962); Kovacs v. Brewer, 356 U.S. 604 (1958):

21. See, e.g., H. Clark, Law of Domestic Relations 326 (1968) [hereinafter cited as Clark]; Fain, Custody of the Children, in 1 California FamiLy LAWYER 54547 (C.E.B. 1961) [hereinafter cited as Fain, Custody]; 2 H. Foster \& D. FREEd, LAW AND THE FAMILY, NEW YORK 553-62 (1966); R. WeINTRAUB, COMMENTARY ON THE CONFLICT OF LAWs $197-99$ (1971); Ehrenzweig, The Interstate Child and Uniform Legislation: A Plea for Extralitigious Proceedings, 64 Mich. L. REv. 1, 1 (1965); Ratner, Child Custody in a Federal System, 62 MicH. L. REv. 795, 798 (1974); Comment, Conflicting Custody Decrees: In Whose Best Interest? 7 DuQ. L. REv. 262, 266 (1969); Comment, Children in Transit: Child Custody and the Conflict of Laws, 6 U. CAL. D.L. REv. 160, 161-62 (1973); Comment, The Puzzle of Jurisdiction in Child Custody Actions, 38 U. Colo. L. Rev. 541, 542-43 (1966); Note, Ford v. Ford: Full Faith and Credit to Child Custody Decrees? 73 YaLE L.J. 134, 139 (1963). See gen- 
Almost any state may take jurisdiction to determine custody, even if the child has been brought into the state to evade an unfavorable decree elsewhere or is present merely as a visitor. ${ }^{22}$

Some states announce that they will accord comity recognition, or full faith and credit, to another state's judgment, but immediately qualify that principle by invoking the change-of-circumstances rule and requiring an independent examination of the facts to redetermine the best interests of the child. ${ }^{23}$ When a child has been brought to the forum state by a kidnapper or otherwise in violation of another state's judgment, however, a number of states will apply the "clean hands" rule and directly enforce the prior judgment without rehearing. ${ }^{24}$ The clean hands rule has one important exception: if a state modifies its own custody decree to give custody to the other parent in order to pumish the prior custodian, other states will refuse to enforce the punitive decree. ${ }^{25}$

Whatever principles are announced, the ultimate decision in a great many cases himges on the particular trial judge's opimion of whose custody would be in the best interests of the child, regardless of any prior judgment in another state. Thus, children are often tossed-or stolen-back and forth from one parent to the other; multistate litigation may continue until the fight has exhausted one parent's financial or mental resources or until the child is old enough to call a halt to the vicious game.

\section{B. The Uniform Child Custody Jurisdiction Act}

In preparing the Uniform Act, the Commissioners on Uniforin State Laws found that traditional custody conflicts law had overem-

erally Bodenheimer, Judicial and Legislative Cures for Child Custody Ills, 12 JUDOEs' J. 82 (1973); Bodenheimer, The Rights of Children and the Crisis in Custody Litigation: Modification of Custody In and Out of State, 46 U. CoLo. L. REv. 495 (1975) [hereinafter cited as Bodenheimer, Rights of Children]; Bodenheimer, The Uniform Child Custody Jurisdiction Act, 3 FAM. L.Q. 304 (1969); Bodenheimer, The Uniform Child Custody Jurisdiction Act: A Legislative Remedy for Children Caught in the Conflict of Laws, 22 VAND. L. REV. 1207 (1969) [hereinafter cited as Bodenheimer, Legislative Remedy].

22. Recent decisions reflecting this problem include Spencer v. Spencer, 305 So. 2d 256 (Fla. App. 1974); Roebuck v. Roebuck, 162 Mont. 71, 508 P.2d 1057 (1973); Mrovczynski v. Mrovczynski, 142 N.J. Super. 312, 361 A.2d 554 (App. Div. 1976); Adams v. Bowens, 230 S.E.2d 481 (W. Va. 1976).

23. See, e.g., Roebuck v. Roebuck, 162 Mont. at 77, 508 P.2d at 1061-62.

24. See, e.g., Wilsonoff v. Wilsonoff, 514 P.2d 1264, 1268 (Alas. 1973); Forsyth v. Forsyth, 14 Wash. App. 909, 546 P.2d 117 (1976); Fain, Custody, supra note 21, at 546; Ehrenzweig, Interstate Recognition of Custody Decrees, 51 MicH. L. REv. 345 (1953) [hereinafter cited as Ehrenzweig].

25. E.g., Berlin v. Berlin, 21 N.Y.2d 371, 235 N.E. 2d 109, 288 N.Y.S.2d 44 (1967), cert. denied, 393 U.S. 840 (1968). See Ehrenzweig, supra note 24, at 370-71. For a further discussion of punitive decrees, see text accompanying notes 148-179 infra. 
phasized the modifiability of custody decrees at the expense of the child's primary need for a stable home environment and continuing personal attachments. ${ }^{26}$ The idea that custody judgments should always be fluid and temporary ${ }^{27}$ was rejected as a misconception of children's needs that had persisted to satisfy the desires of feuding parents rather than the rights and interests of children. The traditional approach had treated interstate custody law as a stepchild of conflicts law by withholding the security of the full faith and credit clause, although children need this constitutional support as much or more than money judgment creditors. ${ }^{28}$

A growing recognition of the limited capacity of a judge or any other professional to reach the "right" decision in a custody case also contributed to the Uniform Act. This is particularly true when both parents are capable of rearing the child. ${ }^{29}$ Moreover, the second or third judge relitigating the issue will rarely have better answers than the first, or than the parents themselves whose prior agreement may have been incorporated into the original decree. ${ }^{30}$

The Uniform Act reflects this reorientation of attitudes by severely restricting a court's power to change custody decrees rendered in another state. In addition it seeks to bring some order imto the existing chaos and to restore the public's confidence in the ability of the law to supply solutions to their problems. ${ }^{31}$

The Uniform Act requires the courts of a state that adopts it to recognize and enforce the custody decree of another state if that state had jurisdiction to render the decree. Jurisdiction of the rendering state exists and must be honored if it was assumed under statutory

26. UNIForm ChILd CUSTOdY JuRisdiction Act, Commissioner's Prefatory Note.

27. See, e.g., Kovacs v. Brewer, 356 U.S. 604, 612 (1958).

28. See Bodenheimer, Legislative Remedy, supra note 21, at 1210, 1212.

29. See Dembitz, Beyond Any Discipline's Competence, 83 Yale L.J. 1304 (1974). See also J. Goldstein, A. Freud \& A. Solnit, Beyond the Best INTEREsts OF THE CHILD 49-52, 63 (1973).

30. These ideas have been convincingly articulated by Professor Mnookin, who states that "the determination of what is 'best' . . f for a child is usually indeterminative and speculative"; and that one of the few guidelines we have-based on an "impressive consensus . . . among psychologists and psychiatrists"-is the fact that "continuity and stability in relationships are . . important for children." In view of the inevitable uncertainty and indeterminacy of the best interests standard, Professor Mnookin adds, the parties should be encouraged to work out their own resolution of the custody issue, and failing that, "any reform effort should be . . . directed toward insuring that courts . . . decide, decide promptly, and decide once and for all." Mnookin, Child-Custody Adjudication: Judicial Functions in the Face of Indeterminacy, 39 LAW \& CoNTEMP. PROB. 226 at 229, 265, 292 (1975). On the use of counseling to help parents reach agreement on custody, see, e.g., H. Clark, Cases and Problems on Domestic ReIATMONS 658 (2d ed. 1974); Bodenheimer, Rights of Children, supra note 21, at 50708.

31. See UNIFORM ACT, Commissioners' Prefatory Note. 
standards substantially in accordance with those of the Act, or if the facts of the case would justify that state's jurisdiction under the Act. ${ }^{82}$ The state that rendered the decree has continuing jurisdiction; ${ }^{33}$ modifications of custody by another state are prohibited unless the prior state's jurisdiction has ended or has been declined on the ground of inconvenience of the forun. ${ }^{34}$

Initial jurisdiction under the Act is vested in the child's home state $^{35}$ or a state with which the child and a parent or other contestant has a "significant connection." 36 The physical presence of the child and one contestant does not in itself confer jurisdiction ${ }^{37}$ unless there is a genuine emergency. ${ }^{38}$ Conversely, the physical presence of the child is not a prerequisite to jurisdiction. ${ }^{39}$ The home state retains jurisdiction for at least 6 months after the child's removal or departure; ${ }^{40}$ its power may continue even after the 6 month period, under the "significant connection" provision." A state that lacks subject unatter jurisdiction under the "home state" or "significant connection" provisions of the Act does not acquire jurisdiction through the contestants' acquiescence. ${ }^{42}$

The Act contains a forum non conveniens section tailored to child custody cases $^{43}$ and provisions to avoid simultaneous proceedimgs in more than one state. ${ }^{44}$ Several sections encourage interstate cooperation, communication between courts of different jurisdictions, and interstate assistance in factfinding and in the resolution of jurisdictional conflicts. $^{45}$ The Act contains an optional "clean hands" provision as

32. UNIform Act $\S \S 13,15$, Cal. Clv. CODE $\$ \S 5162,5164$ (West. Supp. 1977). California has adopted the Uniform Act with very few modifications. For the convenience of readers, citations to both the Uniform Act and the California codification are included. All the California provisions may be found in the 1977 West supplement. 23.

33. See UNIFORM ACT $\S 14$, Commissioners' Note; CLARK, supra note 21 , at 322 -

34. UnIform ACT $\$ 14$, Cal. Civ. Code $\$ 5163$.

35. The home state is defmed as "the state in which the child immediately preceding the time involved lived with his parents, a parent, or a person acting as parent, for at least six consecutive months ...", with allowances for temporary absences and children below the age of 6 months. Id., $\S 2(5)$, CAL. CIv. CoDE $\$ 5151(5)$.

36. Id. \& 3(a) (1), (2), CAL. CTV. CODE $\$ 5152(1)$ (a), (b).

37. Id. § 3(b), CAL. CIV. CODE $\$ 5152(2)$.

38. Id. $\S 3(\mathrm{a})(3)$, CAL. CIv. Code $\$ 5152(1)(c)$. On emergency jurisdiction, see text accompanying notes $89-107$, infra.

39. UNIFORM ACT $\$ 3(\mathrm{c})$, CAL. CTV. CODE $\$ 5152(3)$.

40. UNIForm ACT $\$ 3(\mathrm{a})(1)$ (ii), CAL. Crv. CODE $\$ 5152$ (1) (a) (ii).

41. Id. $\$ 3(\mathrm{a})(2)$, CAL. CIv. Code $\$ 5152(1)(\mathrm{b})$. The extension of jurisdiction for six months or more is of particular importance when a child disappears or is removed from the state prior to a custody adjudication. See text accompanying notes 72-80 infra.

42. See text accompanying notes 121-130 infra.

43. UNIFORM ACT $\$ 7$, CAL. CIV. CODE $\$ 5156$.

44. Id. § 6, CAL. CIV. CODE $\$ 5155$.

45. Id. $\S \S 1,6,7,16-22, \mathrm{CAL}$. CIv. CoDE $\S \S 5150,5155,5156,5156-5171$. See 
a subsidiary deterrent to forum shopping, ${ }^{46}$ although the recognition and nonmodification mandates will usually suffice to deter child stealmg or changes of custody during visits. ${ }^{47}$ The Act does not require reciprocity ${ }^{48}$ it can be put into immediate operation by each enacting state. Its provisions apply to international as well as interstate cases. ${ }^{49}$

\section{II}

\section{APPLICATION OF THE UNIFORM ACT}

The case law presently available ${ }^{50}$ indicates that the major objectives of the Act are being achieved, although initial lack of familiarity with the Act has produced a few questionable decisions. ${ }^{51}$

\section{A. Return of Child after Out-of-State Visit}

A child who visits a noncustodial parent in a state not governed by the Act cannot be certain of returning home, for a court of the visited state may transfer custody. ${ }^{52}$ This very real possibility places "a premium on the abuse of the right of visitation and make[s] it difficult for parties to agree on the free movement of the child from one

also id., $\S 9$, CAL. Crv. CODE $\S 5158$, which requires every party to inform the court as to prior or pending custody cases in other jurisdictions; the obligation to inforn the court is a contmuing one covering new developments during the current proceediugs.

46. Id. $\$ 8$, CAL. CTv. CODE $\$$ 5157. See text accompanying notes $24-25$, supra.

47. If a court in another state has continuing jurisdiction, the forum state inust defer to that jurisdiction under section 14 of the Act. As a rule, therefore, the kidnapper has no access to a court in another state even without the application of a clean hands rule. See UNIForm AcT \$ 8, Commissioners' Note. For an enlightening comparison of the clean hands principle with the full faith and credit principle, see Application of Lang, 9 App. Div. 2d 401, 193 N.Y.S.2d 763 (1959), aff'd, 7 N.Y.2d 1029, 166 N.E.2d 861,200 N.Y.S.2d 71 (1960), discussed in Bodenheimer, The International Kidnapping of Children: The United States Approach, 11 FAM. L.Q. 83, 88-91 (1977). Section 8 (a) of the Uniform Act extends the cleau hands rule to child removals prior to a custody decree. See text accompanying notes 72-80 infra.

48. The Commissioners on Uniform State Laws followed the example set by Wisconsin case law, which has long honored the custody judgments of other states without expectation of reciprocity. See, e.g., State ex rel. Kern v. Kern, 17 Wis.2d 268, 116 N.W.2d 337 (1962). See also note 113 infra. Hawaii is the only adopting state that has added a reciprocity clause. HAw. REv. STAT. $\$$ 583-1(b) (Supp. 1975).

49. UNIFORM ACT $\$ 23$, CAL. Civ. CODE $\$ 5172$.

50. Because most enacting states have adopted the Act recently, the number of published appellate cases under the Act is limited.

51. See, e.g., Nelson v. District Court, 186 Colo. 381, 527 P.2d 811 (1974) (assumption of jurisdiction by a Colorado court to modify custody was upheld, three justices dissenting, even though the child was only visiting in the state); see also Giddings v. Giddings, 228 N.W.2d 915, 918 (N.D. 1975), where the Supreme Court of North Dakota pointed out that the Uniform Child Custody Jurisdiction Act had been overlooked by counsel.

52. See notes 19-25 supra, and accompanying text. 
parent to the other." ${ }^{\text {s3 }}$ The Uniform Act eliminates the incentive for such practices.

In re Custody of Thomas ${ }^{54}$ provides a good example of the Act's operation. The case involved an 8-year-old boy who lived in Kansas in the custody of his mother under a Kansas divorce decree. When the father moved to Colorado, the parents made arrangements permitting the boy to visit his father in the summer. During the second sumnmer visit the father sought permanent custody in a Colorado court. The mother countered with a motion to dismiss for lack of jurisdiction under the Uniform Act, coupled with a writ of habeas corpus. The court held that the continuing jurisdiction of Kansas prevented Colorado from assuning jurisdiction to modify custody; the boy was returned to his mother with little delay or expense to her. ${ }^{55}$ In addition to the out-of-pocket cost of the hitigation, the boy's father lost the confidence of his former wife, making future visits in Colorado difficult to arrange.

In another Colorado case, Custody of Glass, ${ }^{56}$ the ultimate result was the same, but due to the trial court's insufficient familiarity with the Uniform Act, more than a year elapsed before the child was returned. ${ }^{57}$ The parents had been divorced in California, and the mother was awarded custody. She brought their infant child to Colorado, the father's new residence, for a visit. When she telephoned some ten weeks later to arrange for the child's return, the father immediately instituted proceedings in Colorado to secure custody for himself. The trial court awarded custody to the father. ${ }^{58}$ The appellate court reversed, holding that California retained continuing jurisdiction; that the Colorado court lacked power under section 14 of the Uniforin Act to modify the existing California decree; and that the father's "petition for custody . . . should have been addressed to the Superior Court of Mendocino County, California."

53. Bergen v. Bergen, 439 F.2d 1008, 1015 (3d Cir. 1971). See also Nelson v. District Court, 186 Colo. 381, 527 P.2d 811 (1974) (dissenting opinion of Chief Justice Pringle).

54. 36 Colo. App. 96, 537 P.2d 1095 (1975).

55. Id. at $101,537 \mathrm{P} .2 \mathrm{~d}$ at 1097 . The Court relied on various sections of the Act, including section $7(\mathrm{~g})$, to impose the expenses incurred by the mother in recovering the child, including her attorney's fees, on the father. See also UNIFORM ACT, §\$ 8(c), $15(\mathrm{~b})$.

56. 36 Colo. App. 91, 537 P.2d 1092 (1975).

57. Id. at 95,537 P.2d at 1093.

58. The trial court had taken the position that it was not modifying the California decree because there was some evidence, controverted by the mother, that she had voluntarily relinquished the child to the father's custody. Id. at 93, 537 P.2d at 1093. Even if the father's contention had been proved, California had exclusive jurisdiction under the Act to determine whether custody was to be formally changed.

59. Id. at 95,537 P.2d at 1094. In a similar situation, Kentucky returned two 
These cases demonstrate that the Uniform Act is capable of achieving one of its inost basic purposes. The interstate enforceinent of custody decrees will help innumerable children who under the traditional law were "lost" every year through custody changes in visited states. This legal change can give new confidence to custodial parents who send their children out of state for visits, and will promote continuing contact between children and their noncustodial parents.

\section{B. Return of Kidnapped Child}

If the whereabouts of a kidnapping parent are known, a state operating under the Act can return the child to the custodial parent expeditiously. In a recent Califorma case ${ }^{60}$ for example, the father had snatched a young boy from the Nevada home of the custodial mother who had left the child in the care of a babysitter. A day or two after the kidnapping, the mother traveled to the Califorma town where she expected her ex-husband to be. She filed a certified copy of the Nevada decree giving her custody ${ }^{61}$ and petitioned for habeas corpus. The husband was found and served, appeared in court, and was ordered to and did im fact turn the child over to the mother. Only fifteen days had elapsed since the kidnapping.

Had the father in this case cross-petitioned for modification of custody, California would have turned him away for lack of jurisdiction. $^{62} \mathrm{Had}$ he known about the new teeth in Califorma's law, he would have sought modification in Nevada, the state of continuing jurisdiction, to begin with, obviating much commotion and expense, and above all, the trauma brought upon the child by the kidnapping and the habeas corpus proceedings.

In California a bench warrant may be used in lieu of habeas corpus in cases of this kind, ${ }^{63}$ but, as one judge has noted, a warrant should be used with great caution "because this kind of process really does require an arrest of the child, which might mean confinement in a receiving home for many hours . . .."64 This warning is a welcome

children who were visiting their father to the mother, who had custody under a Connecticut decree. Hawley v. Shaver, 528 S.W.2d 669 (Ky. 1975) (decided under Kentucky's enactment of section 3 of the Uniform Act, KY. REv. STAT. $\$ 403.260$ (Supp. 1976) ). Relying on California's adoption of the Uniform Act, a California Superior Court reached the same conclusion in an international case. Morgan v. Morgan, No. P28917 (Super. Ct., Santa Clara County, Cal. Sept. 16, 1975).

60. Order granting writ of Habeas Corpus, No. $204291-9$ (Super. Ct. Fresno County, Cal. June 18, 1976) (name of parties withheld at request of attorney).

61. Pursuant to Uniform ACT \$ 15, CAL. CTv. CODE \$ 5164.

62. See UNIFORM ACT \& 15 , Commissioner's Note.

63. See CAL. Penal Code $\S \S 1497-1501$ (West 1970).

64. Address by Judge Rosado, Annual Convention of California Trial Lawyers Ass'n, San Diego (Nov. 11-13, 1976), reported in 3 FAM. L. REP. (BNA) 2068, 2069 (1976). 
reminder to attorneys and the news media that the futility of parental kidnapping in the growing number of states where the Uniform Act is in force should be inade known to the public so that children will be spared not only the agonizing experience of the kidnapping and its aftermath, but the equally traumatic circumstances surrounding the child's recovery by habeas corpus, warrant, or other pohice action.

\section{Prolonged Retention of the Child in Another State}

The Uniform Act gives jurisdiction to the child's "home state", defined as the state in which the child has resided for the preceding six months. ${ }^{65}$ When a child stays in a state for six months or more as a visitor or a victim of abduction, the question arises whether the new state has power to modify the custody decree. ${ }^{66}$ The answer is that the Act does not permit the second state to take jurisdiction because the paramount jurisdiction of the prior state continues. Section 3 of the Act, the basic provision on subject matter jurisdiction, must be read in conjunction with section 14, which does not permit modifications by another state as long as the prior state's exclusive jurisdiction continues. This is true whether or not another state has technically become the child's home state. ${ }^{67}$ Any other reading of the Act would subvert its purposes by permitting a kidnapper to go into hiding for 6 months and then seek modification, and by encouraging a visited parent to prolong the period of visitation with or without consent of the custodial parent in order to seek modification in the visited state. ${ }^{.8}$ The Act does not support an interpretation which would encourage the very evils the Commissioners on Uniform State Laws intended to eradicate.

65. See note 35 , supra.

66. See B. Bodenheimer, New Developments in Interstate Custody Litigation and the Uniform Child Custody Jurisdiction Act, Symposium, Cal. Trial Lawyers Ass'n, June 12, 1976, at 129, 131 (copy on file at the California Law Review).

67. See UNIForm Act \$ 14, Commissioners' Note:

[T] $\mathrm{f}$ custody was awarded to the father in state 1 where he continued to live with the children for two years and thereafter his wife kept the children in state 2 for $61 / 2$ inonths ( $31 / 2$ inonths beyond her visitation privileges) with or without permission of the husband, state 1 has preferred jurisdiction to modify the decree despite the fact that state 2 has in the meantime become the "home state" of the child.

In fact, state 1 has exclusive jurisdiction in this situation. Cramton, Currae, \& KaY, supra note 6, at 844-45. The first state also retams jurisdiction if the custodial parent has moved away with the children, but the other parent remains in the state of the decree and receives visits from the children there. See id. at 845 , criticizing Turley v. Griffin, 508 S.W.2d 764 (Ky. 1974).

68. See particularly the Act's expressed purpose to "deter abductions and other unilateral reunovals of children undertaken to obtain custody awards." UNIFORM ACT $\S 1$ (a) (5), CAL. CIv. CODE $\$ 5150$ (e) (West Supp. 1977). Of course, the state of the original decree unay wish to decline jurisdiction on inconvenient forum grounds, especially if the child has been away for a long time and has made few visits in the state. See text accompanying notes 108-116, infra. 
While reported decisions do not address this point specifically, the Colorado Supreme Court in Fry v. Ball refused jurisdiction im a custody case despite the child's stay in Colorado for some 8 months. ${ }^{69}$ On the other hand, a recent Oregon case considered the children's presence in that state for approximately 20 months as one reason for its assumption of jurisdiction in an action challenging an Indiana decree although the mother had wrongfully removed the children pending the divorce and the father had been unable to locate them. ${ }^{70}$ If the present wave of child stealings and concealments continues, and parents searching for lost children continue to receive insufficient aid from law enforcement officials, courts will presumably decline to follow the course of the Oregon court. They will instead return all children who are wrongfully taken or detained in violation of a custody decree, perhaps withm an outer limit of 3 or 4 years, depending upon the circumstances. ${ }^{71}$

\section{Child's Removal Prior to Proceedings}

With the growing acceptance of the full faith and credit principle in interstate custody law, the mcidence of child removals before any court proceedings have been instituted seems to be increasing. ${ }^{72}$ Apparently some parents hope that they can keep de facto custody of the child by moving to a new state and staying away from the courts. If such parents do attempt to obtain custody in a new state which has adopted the Uniform Act, they will be turned down for lack of jurisdiction. ${ }^{73}$

The Act provides that the home state's jurisdiction continues for some time after the child's departure. ${ }^{74}$ This is a valuable tool en-

69. Fry v. Ball, 544 P.2d 402 (Colo. 1975), discussed in text accompanying notes 81-88 infra. Cf. Wakefield v. Little Light, 276 Md. 333, 347 A.2d 228 (1975) (jurisdiction refused despite child's 20 months of residency).

70. In re Marriage of Settle, 276 Or. 759,556 P.2d 962 (1976). The court found it impossible, on the facts before it, to reconcile the Act's purpose of deterring parental child abductions with its second objective of protecting the best interests of the child. When a case presents "an irreconcilable conflict between those two interests," the court said, the attempt to achieve both purposes is "schizophrenic." Id. at 761, 556 P.2d at 968. The court's solution was to "read the Act as making predommate the best interests of the children," though it recognized that this "would put a premium upon an improper removal of children from their state of original residence." Id.

71. See, e.g., Smith, In Search of Jolie: A Paper Chase, L.A. Times, April 20, 1976, at 1. It took Jolie's mother, Mrs. Ryan, 22 months of uninterrupted search to locate and recover her child. Interview with Mrs. Ryan (March 3, 1977). Cf. In re B.G., 11 Cal. 3d 679, 523 P.2d 244, 114 Cal. Rptr. 444 (1974) (children not returned to mother after three and a half years of separation).

72. No official statistics are available.

73. See Uniform Act $\$ 3(\mathrm{~b})$, CAL. CTV. CODE $\$ 5152(2)$; furthermore, the cleanhands rule may aso block their access to the courts. Id. § 8(a), CaL. CIv. CoDE § 5157. California has modified this section of the Act. See note 140 infra and accompanying text.

74. Uniform ACT $\$ 3(a)(1)$, CAL. CTv. Code $\$ 5152(1)$ (a). Prompt court pro- 
abling the parent left behind to obtain an early adjudication of custody. This does not inean that the parent in the hoine state will necessarily or generally be awarded custody. The other parent's departure may have been precipitated by intolerable conditions in the home. In any event, the removal of the child in itself ought not to be a factor in the determination of custody. ${ }^{75}$ In the words of Barbara Armstrong, "the well being of the child rather than the punishment or reward of the parent. . ." should guide the custody decision. ${ }^{76}$

In order to avoid preferential treatinent of the parent who remains a local resident, the Act provides various mechanisms to assure the presence of the other parent at the hearing, or, short of that, to channel that parent's out-of-state evidence into the local forum. ${ }^{77}$ Under recent legislation in California, the district attorney will aid in locating the absent parent and procuring compliance witl an order to appear with the child at a custody learing. ${ }^{78}$ If necessary, custody will be determined in the absence of the parent who has left the state, as long as that parent is given proper notice and an opportunity to be heard. ${ }^{79}$ Any resulting custody decree is directly enforceable in a state that has adopted the Act. ${ }^{80}$

\section{E. Fry v. Ball: Colorado Offers Cooperation to California}

In Fry v. Ball ${ }^{81}$ the Colorado Supreine Court, faced with a disquieting set of facts, set im motion an ingenious cooperative scheme, reinvolving the California court that granted the original custody decree and ultimately resulting im a satisfactory solution for the child.

Scott Fry had been placed under the guardianship of his paternal grandmother by a California court when he was 17 months old. His

ceedings are advisable. Home state jurisdiction is retained for 6 months after the child's removal and "significant connection" jurisdiction may continue somewhat longer. See notes 40-41, supra, and accompanying text.

75. See UNIForm MarRiage and Divorce ACT \& 402: ". . . The court shall not consider conduct of a proposed custodian that does not effect his relationship to the child."

76. 2 ARMSTRONG, supra note 1, at 326 (Supp. 1966).

77. UNIForm ACT $\S \S 1,6,7,11,18-20$, CAL. CTv. CODE $\S \S 5150,5155,5160$, 5167-69.

78. CAL. CTv. CoDE $\S 4604$ (West Supp. 1977). See text accompanying notes 133-140 infra.

79. UNIFORM ACT $\S \S 4,5,12$, CAI. Civ. CODE $\S \S 5153,5154,5161$ (West Supp. 1977).

80. Id. $§ 15$, CAL. Civ. Code $\S 5164$. See People ex rel. Loeser v. Loeser, 51 IIl. 2d 567, 283 N.E.2d 884 (1972) (Illinois, a nonenacting state, enforced an Indiana custody award to the father by way of habeas corpus without an evidentiary hearing where the mother, who was duly served, had left Indiana prior to the commencement of the divorce proceedings.)

81. 544 P.2d 402 (Colo. 1975). 
father was then in jail awaiting extradition to Oregon on charges of selling narcotics; his mother was undergoing treatunent for heroin addiction. Two years later the grandparents inoved to Colorado, unaware that California guardianship law required court permission to leave with the child. ${ }^{82}$ Scott's parents subsequently petitioned for termination of the guardianship. ${ }^{83}$ The court found that the guardianship was no longer necessary, and granted the petition. ${ }^{84}$ When the parents caine for the boy in Colorado, a scuffle ensued. Both parents were arrested and charged with assault. The grandparents then obtained an ex parte order froin a Colorado court restoring physical custody of Scott to them. The parents sued in the Supreme Court of Colorado to enjoin the lower court froin exercising jurisdiction under the Uniform Act.

The Colorado Supreme Court ruled that the Colorado court must defer to the jurisdiction of the Califorma court, following the Act's "general pohicy which favors the continuing jurisdiction of the court rendering the original custody decree." 85 Nevertheless, the court felt that it was urgent ro relay to the California court certain information that had surfaced in Colorado, such as the physical violence accompanying the parents' seizure of the boy, indications that Scott feared his father, and the parents' background of heroin addiction. The court noted that the Uniform Act calls for "cooperation between courts of different states which will lead to an informed decision on custody." Accordingly, "under its equity powers," remain im the temporary custody of his grandmother for $\mathbf{5 0}$ days to give her an opportunity to petition for modification in California. If such a petition were not filed and diligently prosecuted, the grandmother's temporary custody was to terminate. In any case, the Colorado courts were to recognize the final California decree, whatever its nature.

The grandmother then sought reinstatement of the guardianship in California. The Colorado Supreme Court opinion forned a proininent part of her pleadings. When it became known shortly before trial

82. 544 P.2d at 404. The guardianship regulation is contained in CAL. PROB. CODE $\$ 1500$ (West 1956).

83. The grandmother was served personally in Colorado and appeared by counsel.

84. The probate judge also took into consideration the grandmother's departure without his permission and her failure to appear personally in the termination proceedings. Interview with Sheldon S. Goodman, attorney for the grandmother (Dec. 21, 1976).

85. $544 \mathrm{P} .2 \mathrm{~d}$ at 406 .

86. Id. at 407 , referring to UNIFORM ACT $\$ 1$. The Colorado court declared that "the courts of this state stand ready to aid the [California] Superior Court consistent with the letter and spirit of the Uniform Child Custody Jurisdiction Act." Id. at 408.

87. 544 P.2d at 408. The Court apparently relied on its parens patriae or emergency powers, embodied in UNIFORM ACT $\$ 3(a)(3)$. See text accompanying notes 89106 infra. 
that Scott's mother was in jail on drug-related charges, the parties stipulated to an order providing that the parents would move to Colorado and establish residence with the grandparents in an effort to reconcile. If the plan of reconciliation should fail, the order provided that California would be deemed an inconvenient forum and that in any event the matter would be transferred to a Colorado court. ${ }^{88}$ This venture in interstate cooperation demonstrates how the Act permits a court to safeguard the child and still prevent forum shopping by the loser in a custody contest. The Colorado Supreme Court's wise choice of remedies combines temporary protection of the child in an einergency with an offer of interstate judicial cooperation.

\section{F. Emergency Jurisdiction}

One of the basic tenets of the Act is that the physical presence of a child in a state does not confer on that state jurisdiction to modify custody if another state has jurisdiction. ${ }^{89}$ Only when a child is stranded or abandoned in the state, or there is an emergency arising from mistreatment, abuse or neglect, may the state where the child is present take protective measures. The Commissioners intended this emergency exception to have a very limited scope: "this extraordimary jurisdiction is reserved for extraordinary circumstances ..... When there is child neglect without einergency or abandoninent, jurisdiction cannot be based on this paragraph."

This exceptional jurisdiction exists in very few cases. Naturally, there will be attempts to circumvent the Act by "shouting fire" in every conceivable situation. ${ }^{91}$ Emergency jurisdiction must be denied, however, when it is invoked as a pretext in order to reopen a custody controversy. ${ }^{92}$ Unless judges and attorneys are constantly alert to the

88. Stipulation to Transfer of Action and Order Thereon, In re Guardianship of Fry, No. A-74196 (Super. Ct., Orange County, Cal. July 23, 1976). (A copy of the 1976 Stipulation and Order is on file at the California Law Review.)

89. UNIFORM ACT $\S \S 3(\mathrm{~b}), 14$, and Commissioners' Notes, CaL. CIv. CODE $\S \S$ 5152(2), 5163. See Fain, The Interstate Child Custody Problem Revisited, 16 A.B.A. Fam. L. Newsletter 1, 11 (1975) [hereinafter cited as Fain, Problem Revisited].

90. UNIFORM ACT $\$ 3(\mathrm{a})(3)$, Commissioners' Note; see Fain, Problem Revisited, supra note 89 , at 12 .

91. See, e.g., Morgan v. Morgan, No. P28917 (Super. Ct., Santa Clara County, Cal. Sept. 16, 1975). (The visited father claimed an emergency existcd because the child needed au operation on his foot in the near future; held, no emergency existed since the operation could be performed after the child"s return to his mother.)

92. The Louisiana Supreme Court took this position in State ex rel. King, denying jurisdiction where a father claimed that his children, who he had brought to Louisiana, had been living in an "injurious environment" in New York, where the children's mother had custody. "Barring an emergency situation, and clear statutory authority," the court held that jurisdiction does not lie when the children are only temporarily present in the state. 310 So.2d 614, 617 (La. 1975). Although the Uniform Act has not been adopted 
dangers inherent in misuses of emergency jurisdiction to circumvent the Act, the exception could tear so large a hole in the Act that custody decrees made in one state would again be relitigated in other states; and the interstate chaos that the Act was intended to remedy would be revived and perhaps intensified.

The question, then, is: What are legitimate uses of emergency jurisdiction?

Clearly, an emergency exists when a child is in immediate danger from a source within the state's borders. ${ }^{93}$ For example, suppose a case in which a child's parents are killed in an accident away from home and the child survives. A court in the state of the accident has jurisdiction to place the child into a temporary home. Or suppose that the custodial parent travels to the state where the child is visiting and threatens the former spouse and the child with violence. Again, the state of the visit has power to intervene. Additionally, an emergency exists if, prior to any custody adjudication, a parent brings the child to a state and the other parent, who still has equal custody rights, follows to claim the child. In such a situation the child has no parent capable of exercismg effective parental control; ${ }^{94}$ the parental feud is fraught with danger for the child so that it is urgent to settle the dispute by way of a temporary custody order pending adjudication in the proper state. $^{95}$

It is less clear whether the emergency clause of the Act can apply when the source of the threatened harm is in another state to which the child is to return. Shortly before the California legislature adopted the Uniforn Act, the California Supreme Court considered such a case in Ferreira v. Ferreira. ${ }^{96}$ While endorsing the principle that courts should show "great respect . . . for existing custody decrees," the court

in Louisiana, it was mentioned by the court and the decision furnishes an excellent example of the application of the Act's policies.

93. This is the traditional basis of parens patriae jurisdiction, which is codified in the Act's emergency exception. UNIFORM AcT $\$ 3(a)(3)$, Commissioners' Note. See Finlay v. Finlay, 240 N.Y. 429, 148 N.E. 624 (1925); ClaRK, supra note 21, at 572.

94. The dispute creates a situation of neglect. See, e.g., CaL. WeLf. \& INST. Code $\S 300$ (a) (West Supp. 1977).

95. For example, after the parents separate in an Eastern state, the father takes the children to California. The mother immediately follows. A California court is without jurisdiction under the Act to adjudicate custody of these temporary residents even if they submit to California's jurisdiction. But the presence of both feuding parents creates a situation of danger for the child, including a risk of violence or abduction, requiring emergency intervention. In such a situation, a Cahifornia court may award temporary custody to the parent who will return the child to his hoine state for adjudication of custody conditional upon such return. For a California decision to this effect, see Balkie v. Balkie, No. D-12-38-03 (Super. Ct., Orange County, Cal. Feb. 25, 1977).

96. 9 Cal. 3d 824, 512 P.2d 304, 109 Cal. Rptr. 80 (1973). 
found that allegations that the children had been beaten by a stepfather in the other state permitted the California court to award temporary custody to the California parent, ${ }^{97}$ and, beyond that, even allowed the court discretion to modify the out-of-state decree on a permanent basis. $^{98}$

Ferreira is sometimes erroneously considered to be an application of the Act, ${ }^{99}$ but under the Act a different result would have been reached. Allegations like those made here would have been read with a healthy suspicion that shortcomings in child rearing, of which no family is free, have been magnified, if not fabricated, to gain access to the forum. As distinguished from Ferreira, the Act does not pernit a permanent custody decree modifying a sister state's judgment, ${ }^{100}$ and its emergency clause embodies a nuch more limited theory of temporary jurisdiction based on possible danger to the child. ${ }^{101}$

If the alleged danger exists in another state, the evidence must, under the Act, be exceedimgly strong to warrant an interference with the jurisdiction of the other state. This does not mean that the state with jurisdiction should not be informed of any allegations of potential harm to the child made in the courts of other states. On the contrary, the Act encourages direct communication between the courts of different states. ${ }^{102}$ Nor need a court without jurisdiction sacrifice the child's

97. Id. at $840,512 \mathrm{P} .2 \mathrm{~d}$ at $314,109 \mathrm{Cal}$. Rptr. at 91 . Although the court insisted that there must be "competent proof, as distinguished from conclusory assertions" of serious jeopardy to the child, id. at 830, 837, 512 P.2d at 307, 109 Cal. Rptr. at 83, 88 , the only evidence offered was the declarations of the father, his attorney, and the children. There was no independent evidence other than a local probation report that contained no out-of-state information. Id. at 832,512 P.2d at 309, 109 Cal. Rptr. at 85.

98. The supreme court, however, counseled the trial court that "ordinarily the California court should . . . issue a stay of the proceedings in this state to permit a final adjudication in the state of the parent entitled to custody under existing decrees. Id. at 842,512 P.2d at 316, 109 Cal. Rptr. at 92.

99. For example, 9 UNIFORM LAWs ANN. (West Supp. 1977) lists Ferreira among the annotations to the Uniform Child Custody Jurisdiction Act. This annotation also lists Comment, The Uniform Child Custody Jurisdiction Act and the Continuing Importance of Ferreira v. Ferreira, 62 Calif. L. Rev. 365 (1974). This Comment, an excellent presentation of the changes made by the Uniform Act, attributes "continuing importance" primarily to Ferreira's innovations with respect to the doctrine of forum non conveniens in areas other than child custody law.

100. Under the Act a "court is not authorized to modify an existing custody decree even in an emergency ...." Custody of Thomas, 537 P.2d 1095, 1097 (Colo. App. 1975). See also Fain, Problem Revisited, supra note 89.

101. Fain, Problem Revisited, supra note 89 , at $10-13$, where the author makes a convimcing comparison of Ferreira with the Act, stating that "temporary jurisdiction exists only when the neglect or abuse is so serious that, in lieu of seeking juvenile court jurisdiction, the Superior Court must act immediately to protect the child." Id. at 12. See also Crampton, CURRIE \& KAY, supra note 6, at 846.

102. See, e.g., UNIForm ACT \& 1(a)(8), CAL. CIV. CODE § 5150(1)(h); Fry v. Ball, 544 P.2d 402, 407 (Colo. 1975). 
protection when an immediate crisis exists, as was the case in $F r y,{ }^{103}$ or in a case where evidence of violent episodes of a psychotic mother was presented to the court. ${ }^{104}$ In such situations the court can retain temporary jurisdiction, leave the children in the temporary custody of the local custodian, and initiate procedures for a reexammation of the case in the court with primary jurisdiction. If this is done under strict time constramts, the danger of temporary local custody draggimg on indefinitely is eliminated. ${ }^{105}$ This scheme, which was employed in Fry, should be the procedure of last resort. Prior to its use, a court should substantiate the allegations of danger. A court might request its probation department or other custody investigation umit to obtain an expeditious on-the-spot investigation and report from its counterpart in the state with jurisdiction where the danger is alleged to exist. ${ }^{106}$ Upon receipt of the out-of-state report and whatever other evidence is available, ${ }^{107}$ the Court would then dismiss the case for lack of jurisdiction or, if the evidence indicates a danger of harm to the child, proceed with the Fry scheme.

\section{G. Use of the Inconvenient Forum: Child's Visit in State of Continuing Jurisdiction}

The child's temporary presence in a state on a visit does not confer custody jurisdiction under the Act. ${ }^{108}$ What would be the consequence if the visited state happens to be the state of the original decree that continues to have jurisdiction? Would the noncustodial parent who has remained in the state have an advantage and a chance to gain custody from the child's custodian who has moved away? It is generally acknowledged that the unfortunate tendency of courts to favor the local petitioner still persists. ${ }^{109}$ Thus the child would be exposed to the risk of having custody transferred to the visited parent.

103. Fry v. Ball, 544 P.2d 402 (Colo. 1975), discussed in text accompanying notes 81-88, supra.

104. Zillmer v. Zillmer, 8 Wis. 2 d 657,100 N.W.2d 564, rev'd per curiam, 101 N.W.2d 703 (1960). This case used temporary emergency jurisdiction, along with a referral of the litigants to the prior forum, before the existence of the Uniform Act.

105. This was a serious loophole under the former Ferreira formula. Fain, Problem Revisited, supra note 89, at 11 . Both Fry and Zillmer imposed strict time limitations on temporary local custody.

106. Such interstate factfinding is authorized by UNIFORM ACT $\$ 19$, CAL. CIv. CODE $\$ 5168$ (West Supp. 1977). Investigation reports from other states are not an innovation of the Act. See, e.g., Wheeler v. Wheeler, 34 Cal. App. 3d 239, 241, 109 Cal. Rptr. 782, 783 (1973).

107. The court in Ferreira suggested affidavits from independent sources such as police departments, public defenders, licensed welfare agencies, doctors, or clergy. 9 Cal. 3d 824, 837, n.15, 512 P.2d 304, 312, 109 Cal. Rptr. 80, 88 (1973).

108. UNIFORM ACT $\$ 3(\mathrm{~b})$, CAL. Civ. CODE $\$ 5152(2)$.

109. See Fry v. Ball, 544 P.2d at 407 (the Act "attempts to counteract this local advantage"). On the unfortunate effects of "hometowning," see Beck, The Law of 
Exactly this danger was present and almost became a reality in Moore v. Moore, ${ }^{110}$ had the Oregon court not averted it by a propitious application of the Act's inconvenient forum rule. ${ }^{111}$ An Oregon divorce court had initially left the 1-year-old child in the custody of her paternal grandmotlier, where she had been placed by the juvemile court because of child abuse by the mother. Several months later the Oregon court granted custody to the father, who subsequently moved to Washington with the child and his second wife. More than two years later, the mother, who had remained in Oregon, petitioned for custady there. She also appeared in proceedings in Washington and asked for custody. The parents agreed to an order in the Washington proceeding granting the mother visitation rights. She brought the child to Oregon on a visit and then refused to return her. The father sought to enforce his custody rights in Oregon, but in the meantine an Oregon trial court had changed custody to the mother.

The main thrust of the court's opinion in Moore was that Oregon's power to modify its own decree in no way required it to exercise that power in all circumstances. It concluded that under the specific guidelines of the forum non conveniens provision of the Uniform Act the trial court should have declined jurisdiction "for a reasonable period ... to allow the institution of an appropriate custodial proceeding by either parent in Washington."112 Oregon's jurisdiction was held to be inappropriate even though no action was pending in Washington when the mother petitioned the Oregon court for the custody change..$^{113}$

Moore set a beneficial precedent that, if emulated by other states, will often solve the problem presented when the noncustodial parent is the only nember of the family still residing in the state of continuing jurisdiction. If the child and the custodial parent have resided in a different state for a considerable period of time, it will be wise in many cases to pass the jurisdictional power on to the new state through the

Child Custody, J. Legal Med., Jan. 1977, at 8cc; Fain, Problem Revisited, supra note 89, at 17; Foster \& Freed, Children and the Law, 2 FAM. L.Q. 40, 49 (1968).

110. 24 Or. App. 673, 546 P.2d 1104 (1976).

111. UNIFORM ACT $\$ 7$, CAL. CIV. CODE $\$ 5156$. Under this section a court may, upon its own motion or that of a party, decline to exercise its jurisdiction if it finds that another forum is more appropriate. Factors to be considered are whether another state is or recently was the child's home state, whether another state has a closer connection with the child and family, whether substantial evidence concerning the child's care and personal relationships is more readily available in another state, and whether the exercise of jurisdiction by the forum state would contravene any of the purposes stated in section 1 of the Act.

112. Id. at $680,546 \mathrm{P} .2 \mathrm{~d}$ at 1109 .

113. The court also refused to be influenced by the potential lack of reciprocity on the part of the other state: "[t]he failure of Washington to have adopted the Uniform Custody Jurisdiction Act . . . is not a barrier." Id. See note 48 supra, and accompanying text. 
inconvenient forum rule. ${ }^{114}$ This device is useful in nıany interjurisdictional situations. It permits a dismissal as well as a stay of proceedings, whether or not the petitioner is a resident of the forum state. ${ }^{115}$ The forum non conveniens provision adds flexibility to some of the Act's more rigid rules and provides an excellent mechanism to avoid jurisdictional conflict. ${ }^{116}$

\section{H. Enforcement of Visitation Rights in Another State}

Under the Uniform Act visitation rights under out-of-state judgments are enforceable to the same extent as primary custody rights. Upon filing the custody decree im another state, its visitation provisions become enforceable in the same manner as orders of the local forum. ${ }^{117}$ Enforcement in most states is by way of contempt proceedings. ${ }^{118}$

If the parents have made specific visitation arrangements before one or both leave the home state and their agreement is incorporated into a court decree, there will be little difficulty in enforcing the decree out-of-state. But many custody judgments merely grant "reasonable visitation privileges." Which court is to interpret the meaning of such a vague order? It would seem reasonable to permit the enforcing state,

114. A Kentucky court, faced with facts similar to those in Moore, denied jurisdiction to modify its own decree. Although the opinion is cast in terms of lack of jurisdictional power, it may be explained as an insufficiently articulated attempt to decline the exercise of that power. Kentucky may have considered itself an inconvenient forum after most family members had left. Turley v. Griffin, 508 S.W.2d 764 (Ky. 1974). On this case see note 67 supra.

115. UNIForm ACT $\S 7$, CAL. Civ. CODE $\S 5156$. As far as child custody law is concerned, the Uniform Act supersedes the Ferreira rule, which permits only a stay when a California resident is involved. See Comment, The Uniform Child Custody Jurisdiction Act and the Continuing Importance of Ferreira v. Ferreira, supra note 99. The Act accords equal treatment to all custody claimants, regardless of their state of residence. Accord, Fain, Problem Revisited, supra note 89, at 11, 12.

116. It has been suggested that a transfer of child custody jurisdiction from one state court to another ought to be required by federal legislation or Supreme Court ruling whenever the custodial parent moves to another jurisdiction. It is further proposed that visits of children under 12 with the other parent be limited to their county of residence. Hudak, The Plight of the Interstate Child in American Courts, 9 ARRON L. REv. 257, 297-300 (1975); Hudak, Seize, Run, and Sue: The Ignominy of Interstate Child Custody Litigation in American Courts, 39 Mo. L. REv. 521, 547-49 (1974). Apart from the question of congressional power to legislate in this area, or the Supreme Court's inclination to enter it, such a rule could cut off all contact between the child and the noncustodial parent. The mconvenient forum rule is the sounder mode of shifting jurisdiction, wheu appropriate.

117. The defirition of "custody determination" includes visitation rights. UNIFORM ACr $\S 2(2)$, CAL. CTV. CODE $\S 5151$ (2) (West Supp. 1977). For enforcenient, see UNIFORM ACT $\S 15$, Cominissioners' Note.

118. See, e.g., Goddard, Family Law Practice, in 5 California Practice $§ 609$ (1972). 
after listening to both sides, and if possible the child, to particularize the visitation provision to fit the new geographical situation. ${ }^{118}$

Very specific visiting schedules present a somewhat more difficult problem. Obviously a custodial parent who has moved to a distant state can no longer comply with the requirement of visits on weekends and certain holidays. Visitation provisions by their nature must be flexible since they must frequently be adjusted to conform to the changing work and school schedules of parents and children and must take account of other changes in family plans, mcluding changes of location. Thus when an out-of-state court must enforce the rights in question, it should have authority to translate the original im-state visiting schedule into a coinparable interstate plan. ${ }^{120}$ This could not include authority to change the primary custody rights. Any changes beyond a readjustment of the prior visiting provisions to allow for geographical changes must remain the provimce of the court with continuing jurisdiction under section 14 of the Act, unless the court declines jurisdiction on imconvenient forum grounds.

\section{Jurisdiction under Uniform Act Not Acquired by Submission to Proceedings}

A state acquires subject matter jurisdiction under the Act if it meets the "home state" or "significant connection" requirements of section 3. Once acquired, jurisdiction continues until all persons involved have moved from the state. ${ }^{121}$ Subject matter jurisdiction, however, may not be conferred by the parties' appearance in the proceedings. ${ }^{122}$

While dicta in a number of cases under the Act have intimated that a state without subject matter jurisdiction under the Act may ac-

119. The only case that mentions visitation rights under the Uniform Act is McDowell v. Orsini, 54 Cal. App. 3d 951, 127 Cal. Rptr. 285 (1976). The father in McDowell demanded visitation rights in a proceeding under the Uniform Reciprocal Enforcement of Support Act. The divorce decree, rendered in New York, had made no provision for custody or visitation. California's jurisdiction to make a visitation order was denied.

120. Post-divorce visitation counselling is helpful to both courts and parents in making the necessary changes. See, e.g., Conciliation Court, Superior Court, Los Angeles County, 1975 Annual Report 26-31 (1975). Counseling prior to a parent's departure is preferable, of course, and would be more readily requested if restraints on moving and punitive custody changes were no longer used in some states. See text accompanying notes 148-179 infra.

121. See UNIFORM ACT $\$ 14$, Commissioners' Notes. On continuing jurisdiction under the Act, see also CRAMPTON, CuRrie \& KAY, supra note 6, at 844-45; Foster \& Freed, Child Snatching and Custodial Fights: The Case for the Uniform Child Custody Jurisdiction Act, 28 HAstings L.J. 1011, 1019 (1977) [hereinafter cited as Foster \& Freed].

122. See, e.g., Sampsell v. Superior Court, 32 Cal. 2d 763, 773, 197 P.2d 739, 746 (1948); F. JAMES, Civil Procedure $\$ 11.6$, at 536-37 (1965). 
quire custody jurisdiction through personal submission to the proceedings, ${ }^{123}$ neither personal jurisdiction over the contestants nor their submission to a court's jurisdiction are enumerated among the jurisdictional criteria listed in the Act. ${ }^{124}$ The Commissioners made this choice purposefully to advance the policies of the Act, as two common fact situations will illustrate.

In the first case, the father removed the child prior to any custody proceedings and a few weeks later petitioned for custody in a new state. The mother, glad to learn the whereabouts of the child from the service of process, rushed to the other state and appeared in the proceedings; but the father obtained custody. Under the Act, the mother's submission to the jurisdiction of a state where the child was merely present did not give subject matter jurisdiction to the court; no enacting state is required to honor the resulting decree.

The second case involves an award of custody to the father in the child's hoine state. The mother, who had moved to another state, apphed for a change of custody in that state while the child was visiting her. The father appeared in the proceedings. If the mother gained custody, this decree is not binding on any enacting state: The visited state had no jurisdiction to modify the decree of the state with continuing jurisdiction. ${ }^{125}$

If the law were otherwise, it would keep courts' doors open to forum shoppers and child abductors, who could achieve their purposes by luring a concerned parent into submitting to another state's jurisdiction. The Uniform Act guards against such occurrences through the restrictive scope of its subject matter jurisdiction.

Surprisingly, Smith v. Superior Court, ${ }^{126}$ California's first published decision under the Act, struggles with the concepts of subject inatter jurisdiction in a case where California clearly had continuing custody jurisdiction. The parties' marriage was dissolved in California and custody of their 2-year-old daughter was awarded to the mother, with visitation rights to the father. Both parties remarried. Mother

123. E.g., Nelson v. District Court, 186 Colo. 381, 387, 527 P.2d 811, 814 (1974); Moore v. Moore, 24 Or. App. 673, 678, 546 P.2d 1104, 1107 (1976); Brooks v. Brooks, 20 Or. App. 43, 50, 530 P.2d 547, 551 (1975).

124. The source of the confusion appears to be the jurisdictional criteria of the Second Restatement of Conflict of Laws, which lists "personal jurisdiction over the persons engaged in the custody controversy" as one alternative basis for subject matter jurisdiction. Restatement (SECOND) of Conflict of LAws $\$ 79$ (c) (1971). See also Sampsell v. Superior Court, 32 Cal. 2d 763, 197 P.2d 739 (1948), on which the Restatement provision is based. The Restatement criteria were not accepted by the Commissioners on Uniform State Laws in drafting the Act. See Foster \& Freed, supra note 121 , at 1023.

125. Uniform Act, § 14, CAL. Crv. Code $\$ 5163$.

126. 68 Cal. App. 3d 457, 137 Cal. Rptr. 348 (1st Dist. 1977). 
and daughter moved to Oregon with the child's stepfather, but contacts between the child and her father in California continued. Several years after moving to Oregon the mother entered into a stipulation with the father particularizing the latter's visitation rights. At the request of both parties the California court modified its decree in accordance with the stipulation. Upon the mother's failure to comply with one of the new visiting provisions, the court found her in contempt. The mother contended that California lacked jurisdiction to enter the modification decree or to hold her in contempt. The appellate court upheld the trial court's jurisdiction. Although the Uniform Act does not alter, but in fact builds on the time-honored rule that custody jurisdiction once acquired continues, ${ }^{127}$ the appellate court reached this conclusion only via the circuitous route of considering both subject matter jurisdiction under the Act and the possible significance of the mother's submission to the personal jurisdiction of California.

The decision in Smith is nevertheless valuable because it confirms that "The Act, of course, generally concerns subject matter jurisdiction . . . and not jurisdiction over the persons of the parents," ${ }^{128}$ and that submission of the parties to a forum does not confer jurisdiction under the Act. ${ }^{129}$

It should be added for purposes of clarification that under the Act personal jurisdiction over each party is not a prerequisite. Once subject matter jurisdiction has been established, the resulting custody decree binds all parties, as long as due process requirements of notice and opportunity to be heard have been met. ${ }^{130}$

\section{III}

\section{SUPPLEMENTAL Legislation}

\section{A. California Parent Locator Act}

One particularly disturbing aspect of child custody disputes, the concealment of children by their parents, is not addressed by the Uni-

127. The court is in error when it assumes that the provisions of the Uniform Act, a special statute, are in conflict with CAL. CIv. PROC. CODE $\$ 410.50$ (b) (West 1973) providing that "Jurisdiction of the court over the parties and the subject matter of an action continues throughout subsequent proceedings in the action." $68 \mathrm{Cal}$. App. 3d at 461, 137 Cal. Rptr. at 351. The Act is entirely consistent with the quoted section; neither does it abrogate CAI. CTV. CODE $\S 4809$ (West 1970) requiring notice to the parties when a court exercises its continuing jurisdiction over child custody. Seo note 121 supra.

128. 68 Cal. App. $3 d$ at 461,137 Cal. Rptr. at 351 (italics in original).

129. Id. at 464-65 n.3, 137 Cal. Rptr. at 353.

130. Uniform ACT $\$ 12$, CAL. CTv. CODE $\$ 5161$, and Commissioners' Notes. Sec also UNIFORM ACT $\$ 13$, Commissioners' Notes; Bodenheimer, Legislative Remedy, supra note 21 , at 1231-35. 
form Act. Although there are no official statistics on parental child concealments, their number appears to be growing, judging from current publicity, the activities of detectives and professional child snatchers, the formation of citizens' groups by those who have experienced such a calamity, and the author's personal observations. ${ }^{131}$ The Act fails to provide a mechamism for detecting the whereabouts of a parent who has disappeared with a child either before or after custody adjudication. ${ }^{132}$ California has filled this gap.

Because the services of private investigators are too expensive for most parents and because such investigators lack access to many important sources of information, the Califorma Legislature passed a parent locator act in $1976 .^{133}$ This statute charges local district attorneys with the responsibility of locating absent parents and children. ${ }^{134}$ If custody has not yet been adjudicated, the district attorney is to procure the absent parent's compliance with a court order to appear with the child for a custody determination. ${ }^{135}$ If the absconding parent has violated an existing custody decree, the district attorney is to assist in its enforcement. ${ }^{136}$ The district attorney acts on behalf of the court, not as the representative of a party. ${ }^{137}$ To carry out this function, the district attorney has the use of the state parent locator service, which was mitially established to enforce delimquent child support decrees, and may obtain further information from the parent locator service of

131. See notes 9-11, supra. One estimate is that there are 25,000 outright kidnappings by parents per year. The cost of locating a kidnapped child is said to range from $\$ 5,000$ to $\$ 10,000$. Oakland Tribune, Jan. 30, 1977, Parade Magazine, at 4. The higher estimate of 100,000 children illegally removed, see text accompanying note 19 supra, includes retentions after visits, probably the most widespread method of taking children from their custodial parents, see text accompanying notes 52-53 supra, and predecree child removals, see text accompanying note 72 supra.

132. Custody proceedings in the child's hoine state can and should be instituted promptly under UNIFORM ACT $\$ 3$ (a) (1) (ii), but a resulting decree cannot be enforced in another state until the whereabouts of the child are known. Cf. Greenberg v. Greenberg, 81 Misc. 2d 180, 365 N.Y.S.2d 400 (Sup. Ct. 1975) (noncustodial inother who disappeared with the child was adjudged in contempt in absentia; the judgment included an order for coinmitment and imprisonment).

133. Ch. 1399, 1976 Cal. Legis. Serv. 6114 (West) (codified in CaL. Crv. Code $\$ \S 4600.1,4604,4605,5157,5160,5169$ (West Supp. 1977), CAL. WELF. \& INST. CoDE $\S \S 11478,11478.5$ (West Supp. 1977), and CaL. Penal Code $\$ \S 278,278.5$ (West Supp. 1977); repealing Cal. Civ. Code $\$ 198$ and Cal. Penal Code $\$ \S 278,279$ ). The Act was preceded by a study and report to the legislature by the Department of Justice. Cal. Dep't of Justice, Report to the Legislature-ACR 236 (1975). The Legislature did not adopt all the Report's recommendations.

134. Cal. Civ. CoDE $\$ \S 4604$ (a), (b) (West Supp. 1977).

135. Id. \$ 4604(a).

136. Id. $\$ 4604(\mathrm{~b})$.

137. Id. $\S 4604$ (c). The expenses of the district attorney, including expenses incurred in a sister state, are paid by the state, subject to reimbursement, if appropriate, by either or both parties. Id. $\$ 4605$. 
the United States Department of Health, Education and Welfare. ${ }^{138}$ Once this program is fully implemented and energetically pursued, it should be successful in finding many children living as fugitives with abducting parents. In addition, the Locator Act tightens the criminal law on child abductions by parents and others, permitting these offenses to be treated as felonies. ${ }^{130}$ The Locator Act also amends a few provisions of the Uniform Act. It provides, annong other things, that a California court presented with a petition to modify the custody decree of another state by a person in possession of the child must notify the person with legal custody and the prosecuting attorney in the other state so that the child can be returned to the legal custodian. ${ }^{140}$

\section{B. Proposed Federal Legislation}

In January, 1977 Congressinen Moss and Edwards introduced a bill in the House of Representatives which would grant full faith and credit to custady decrees. ${ }^{141}$ This bill, H.R. 988, would require each state to enforce the custody orders of other states. Modification petitions are to be addressed to the court of the state that rendered the original decree. If that judicial authority no longer has or declines to exercise jurisdiction, a modification request may be directed to a state that has jurisdiction under its own law. ${ }^{142}$

H.R. 988 is designed to complement the Uniform Act. ${ }^{143}$ If enacted, it would accoinphish on a nationwide level one of the major purposes of the Act, that is, the recognition of out-of-state custody decrees. It would also encourage states to adopt the Uniform Act, because the Act's provisions relating to custody jurisdiction, the enforcement of sister state orders, and interstate judicial assistance and cooperation dovetail with the federal bill.

138. CaL. Welf. \& INST. Code $\S \S 11478,11478.5$ (West Supp. 1977).

139. See Cal. Penal Code $\$ \$ 278,278.5$ (West Supp. 1977).

140. Cal. Crv. Code $\$ 5157$ (West Supp. 1977). Under this amendment, the court is to advise a petitioner who is refused access to a California court under section 5157 (UNIFORM ACT \$ 8) or under section 5163 (UNIFORM ACT $\$ 14$ ) that any petition for modification of custody must be directed to the appropriate court of the state that has continuing jurisdiction. The amendment also adds a provision relating to child removals prior to a custody decree. CAL. Crv. CODE $\$ 5157(3)$ (West Supp. 1977). The Locator Act also amends CAL. Clv. CODE $\$ \S 5160(1)$ and $5169(3)$ (West Supp. 1977) (UNIFORM ACT $\S \S 11(a)$ and $20(c)$ ), regarding orders to appear in custody proceedings, by authorizing the issuance of a warrant of arrest under some circumstances to secure the appearance of the person who has physical custody of the child.

141. See 123 CoNG. Rec. H54 (daily ed. Jan. 4, 1977) (remarks of Rep. Moss). The bill's sponsors included 25 other representatives; an identical bill, numbered H.R. 989 , has been introduced to accomodate cosponsors.

142. H.R. 988, 95th Cong., 1st Sess. (1977). The bill would exercise congressional power to legislate granted by the full faith and credit clause of the Constitution. Id., introductory clause.

143. See 123 Cong. Rec. H54 (daily ed. Jan. 4, 1977) (remarks of Rep. Moss). 
Another possible federal supplement to the Uniform Act is an amendment to the federal kidnapping statute. Bills removing the present exemption of parents who abduct their own children from the statute's criminal sanctions ${ }^{144}$ have been proposed, ${ }^{145}$ but have not yet been adopted. The Department of Justice and the F.B.I. have opposed such legislation because of their reluctance to become involved in domestic relations controversies. ${ }^{146}$ Should such a proposal gain passage it may have a deterrent effect on child snatching by parents or their agents and may aid local officials in their search for missing children under state parent locator acts.

\section{IV}

\section{INTRASTATE ObstaCles to INTERstate SANITy}

The interstate scheme of the Uniform Act is capable of accomplishing as inuch as the law can do in an area as personal as child-parent relationships. Because it is based on the principle of honoring the custody decisions of other jurisdictions, the Act's successful operation depends to a large extent on the nature of those decisions. At the pre, sent time three local practices in custody decision making-punitive custody modifications, joint custody decrees, and unnecessary custody changes-place particular strains on the interstate system. ${ }^{147}$ In these areas, reexamination of local law and procedures, new judicial approaches, and perhaps some legislative changes will be required before imterstate and local law can form a harmonious system.

\section{A. Punitive Custody Modifications}

A major obstacle to interstate harmony is the practice of transferring custody to the other parent to punish the custodial parent for leaving the local jurisdiction. Although the Uniforn Act requires recogni-

144. See note 11 , supra.

145. E.g., H.R. 113, 94th Cong., 1st Sess. (1975) (reprinted in Cal. Dep't. of Justice, supra note 133, appendix 2).

146. Testimony of United States Deputy Attorney General John C. Keeney before the Subcommittee on Crime of the United States House of Representatives Committee on the Judiciary, reprinted in Cal. Dep't of Justice, Report to the Legislature-ACR 236, Appendix 3 (1975).

147. Partiality toward the resident parent presents similar problems. See note 109 supra and accompanying text. This type of problent is not posed by initial custody determinations that are "wrong" in the opinion of a subsequent judge, see text accompanying notes 29-30, supra; that are based on parental agreements without a full court hearing, as is the case in the great majority of custody decrees, see, e.g., CLARK, supra note 21, at 590, Mnookin, supra note 30, at 267; or that are entered without the participation of one parent, if that parent has had an opportunity to enter the proceedings, see note 80 , supra. In all these cases, there is no question that courts in other jurisdictions must enforce the decree if the rendering court had jurisdiction under the Act. 
tion and enforcement of out-of-state custody decisions in general, punitive decrees do not command the respect that is due other out-ofstate custody decrees and should not be recognized under the Act. Pumitive decrees are disfavored because they disrupt the stability and continuity of the child's environment. Moreover, the punishment of a parent who exercises the right to a change of residence raises a serious question of violating the constitutional right to travel.

\section{Examples of Punitive Custody Changes}

A prominent case sanctioning a punitive custody modification is Fritschler v. Fritschler. ${ }^{148}$ A Wisconsin trial court had denied the mother's request for permission to move to Colorado with the children. Her reasons for the move included good job opportunities for herself, better recreational facilities for the children, and a chance "to make it on her own in new surroundings without any help or hindrance from her former husband." ${ }^{149}$ When the mother moved despite the prohibition, custody was transferred to the father. The trial court found her reasons for moving imsufficient and declared that the "children should be able to enjoy and bask in the delights of their father's reputation as a competent and leading attoruey of the City of Madison."160 The Wisconsin Supreme Court upheld the change. Although the court acknowledged that the father could easily visit the children in Colorado and enjoy visitation rights in Wisconsin during the summer months, it declared that "[1]iving in Colorado is not as conducive to a normal relationship between a father and his children, from the children's standpoint as living in the same city."151 This was a punitive decree in its purest form. The mother was punished for disobeying the court-and for desiring a life of her own. As a result the children's lives were disrupted. The custody change was based on the mother's "guilt" in disregarding the court's questionable restriction, a matter clearly unrelated to the welfare of the children.

Unfortunately, Fritschler is not an isolated case, as recent opinions from Maryland, ${ }^{152}$ Florida, ${ }^{153}$ and New York ${ }^{154}$ imdicate. In Minne-

148. 60 Wis. $2 d 283,208$ N.W.2d 336 (1973).

149. Id. at 287,208 N.W.2d at 338.

150. Id. at 292,208 N.W.2d at 341 .

151. Id. at 289,208 N.W.2d at 339 . Justice Hausen, joined by Justice Wilkie, strongly dissented. Id. at 292,208 N.W.2d at 340.

152. In the now classic case of Berlin v. Berlin, 239 Md. 52, 210 A.2d 380 (1965), Maryland transferred custody of two children to their father because the mother, with whom the children had lived in New York for six or seven years, had disobeyed the visitation provisions of the Maryland decree. New York refused recognition to this puuitive modification because of its disruptive effect on the lives of the children. Berlin v. Berlin, 21 N.Y.2d 371, 235 N.E.2d 109, 288 N.Y.S.2d 44 (1967), cert. denied 393 U.S. 840 (1968). For a discussion of the Berlin case, see Bodenheimer, Legislative Remedy, supra note 21 , at $1238-40$. 
sota, punitive custody reversals are authorized by statute. ${ }^{155}$ Recent decisions from other jurisdictions, however, reject change of residence as a reason to modify custody. ${ }^{156}$ In California, the trend is not yet clear. ${ }^{157}$ Although some courts still engage in the highly questionable

153. Scheiner v. Scheiner, 336 So.2d 406 (Fla. App. 1976), upheld an injunction restraining a custodial mother from carrying out her plan to move to California pending a hearing. The court conceded that the injunction was contrary to Florida's prior case law, but maintained that the new Dissolution of Marriage Act increased the father's rights to the extent that his visiting rights must be protected by the continued residence of mother and children in the State.

154. A New York trial conrt transferred custody of a 7-year-old girl to the father when the custodial mother moved to Australia with her new husband. O'Shea v. Brennan, - Misc. 2d - 387 N.Y.S.2d 212 (Sup. Ct. 1976). Ironically, at about the same time, an Australian court changed custody of two children to the father when the inother, who had the children's custody for 9 years, left the country to take up residence in California. Miller v. Miller, Family Court of Australia, No. S2408 (Sydney, 1976). For subsequent litigation of this case in California, see Miller v. Superior Court, 69 Cal. App. 3d 191, 138 Cal. Rptr. 123 (2d Dist. 1977), hearing granted, No. 77-118 (Calif. July 18, 1977), discussed in note 169 infra.

155. Minn. Stat. Ann. \$ 518.175(3), (4) (West 1976). See Ryan v. Ryan, 300 Minn. 244, 219 N.W.2d 912 (1974).

156. The Supreme Court of Montana recently returned two children to their custodial mother who had moved to California after the lower court had given custody to the father upon her departure. Erhard v. Erhard, 554 P.2d 758 (Mont. 1976). Despite a prior antiremoval policy, a New Jersey court permitted a custodial mother to move to South Carolina as long as the children would ke returned for three visits per year. The court, confident that the visiting provision would be complied with, made the perceptive comment that:

the alternative of uninterrupted visits of a week or more in duration several times a year, where the father is in constant and exclusive parental contact with the children and has to plan and provide for them on a daily basis, may well serve the parental relationship better than the typical weekly visit which involves little if any exercise of real paternal responsibility.

D'Onofrio v. D'Onofrio, 144 N.J. Super. 200, 204, 365 A.2d 27, 30 (Ch. Div.) aff'd per curiam, 144 N.J. Snper. 352, 365 A.2d 716 (App. Div. 1976). Similarly, the Supreme Court of Iowa refused a noncustodial father's petition for a custody change after the mother, who had lived within a few blocks of the father, secured employment in a far-removed town within the state. In this case the court felt it desirable to put some distance between the parents because the friction between them had caused emotional stress to the children. In re Guttemuth, 246 N.W.2d 272 (Iowa 1976). Cf. Bolenbaugh v. Bolenbaugh, 237 N.W.2d 12 (S.D. 1975) (custody award to mother upheld although she chose to live in her native Scotland).

157. One recent case clearly heeded Professor Armstrong's admonition that the well-being of the child rather than the punishment or reward of the parent should be the court's concern in custody awards and modifications. In re Marriage of Stoker, 65 Cal. App. 3d 878, 135 Cal. Rptr. 616 (2d Dist. 1977), held that it was improper to modify custody in order to punish the father. But the court in another recent California case, In re Marriage of Ciganovich, 61 Cal. App. 3d 289, 132 Cal. Rptr. 261 (3d Dist. 1976), would not exclude the custodial mother's move to Nevada as one factor, among others, in considering a modification of custody. See generally Miller v. Superior Court, 69 Cal. App. 3d 191, 203-04, 138 Cal. Rptr. 123, 129-30 (2d Dist. 1977), discussed in note 169 infra. Other California cases have condemned punitive measures involving child custody and support. See, e.g., McDowell v. Orsini, 54 Cal. App. 3d 951, 96364, 127 Cal. Rptr. 285, 293 (2d Dist. 1976); Ernst v. Ernst, 214 Cal. App. 2d 174, 29 Cal. Rptr. 478 (2d Dist. 1963) (child may not be punished by withholding his support 
practice of modifying custody in order to punish a parent, courts generally do not honor the punitive custody decrees of other states. ${ }^{168}$

\section{Nonrecognition of Punitive Custody Changes Under the Uniform Act}

The Uniform Act itself does not explicitly provide an exception for punitive decrees, but the comments to the Act and its underlying policies do support such an exclusion. ${ }^{158}$ Two Oregon decisions acknowledged the punitive decree exception and have clarified its scope under the Act. In Brooks v. Brooks, ${ }^{160}$ custody of two children had been awarded to the mother in a Montana divorce. After continuous feuding over visitation the mother secretly moved to Oregon. Montana thereupon granted custody to the father. Upon the father's petition in Oregon to enforce Montana's custody modification, the court found that the father had obtained the Montana decree "solely on the basis of ... allegations of interference by the mother with his legal rights of visitation and periodic custody." 161 The Court concluded that under these circumstances the order was punitive, and the trial court's refusal to honor and enforce the Montana order was warranted.

In a subsequent case, Oregon appropriately distinguished between a punitive custody modification and an initial decree which may have been partially based on disciplinary considerations. The mother in Settle v. Settle ${ }^{162}$ had left Indiana with the children before the Indiana divorce proceedings she had instituted were concluded. The father was awarded custody after a liearing. The Oregon court found that the mother had passed up the opportunity to submit her evidence by voluntarily leaving the state, ${ }^{163}$ and refused to disregard the Indiana decree. It concluded that the order

was not punitive in the narrow sense necessary before a court of this state will ignore a sister state's decree. . . . Brooks involved a typical punitive decree. . . . The Montana court [in Brooks] granted [the father's] request presumably out of frustration over the inother's defiance of its decree. In this and similar situations, the modifica-

when the custodial parent moves from the state); Forslund v. Forslund, 225 Cal. App. 2d 476, 37 Cal. Rptr. 489 (1st Dist. 1964) (custodial husband's move from California to Vermont without prior notice not ground for custody change).

158. See note 25 supra, and accompanying text.

159. UNIFORM ACT $\S \S 13,14$, Commissioners' Notes.

160. 20 Or. App. 43, 530 P.2d 547 (1975).

161. Id. at 51,530 P.2d at 551 .

162. 25 Or. App. 579, 550 P.2d 445 (1976), rev'd on other grounds, In re Marriage of Settle, 276 Or. 759, 556 P.2d 962 (1976). The Oregon Supreme Court expressed agreement with the appellate court's application of the punitive decree rule in Brooks and Settle. Id. at 767, $556 \mathrm{P} .2 \mathrm{~d}$ at 967.

163. 25 Or. App. at 584, 550 P.2d at 447 . 
tion is punitive and not entitled to recognition in other states. The original decree here was not punitive in this sense. ${ }^{104}$

Thus, not every decree that may reflect some disapproval of a parent's conduct falls under the exception.

Brooks and Settle rely on comments to the Act by the Commissioners on Uniform State Laws, ${ }^{165}$ mcluding the reference to Professor Ehrenzweig's articulation of the equitable exception regarding punitive nodifications. ${ }^{168}$ The decisions represent sound interpretations of the Act in the light of its objective to "discourage continuing controversies over child custody in the interest of greater stability of home environment." 167 By containing the equitable exception within narrowly circunscribed limits, these cases at the same time serve the Act's niajor purpose of promoting the interstate recognition of decrees. ${ }^{168}$ Thus the punitive decree exemption should apply only when the court of continuing jurisdiction deprives the custodial parent of custody primarily on the ground that the parent violated sonie provision of the prior decree or moved froin the jurisdiction, whether or not the departure was in contravention of a court order. ${ }^{169}$

164. Id. at 583, 550 P.2d at 446-47. Cf. Petition of Giblin, 232 N.W.2d 214 (Minn. 1975) (state with continuing jurisdiction changed custody from the mother to the father after considering the mother's conviction for welfare fraud, her presentencing report, and a custody investigation report on the father's competence as the children's custodian).

165. UNIFORM ACT $\$ 13$, CoInmissioners' Note.

166. Ehrenzweig, supra note 24, at 370, 373-74. See Brooks v. Brooks, 20 Or. App. at 53, 530 P.2d at 552; Settle v. Settle, 25 Or. App. at 581, 550 P.2d at 446.

167. UNIForm ACT $\$ 1(4)$, CAL. CTv. CoDe $\$ 5150$ (d) (West Supp. 1977).

168. In view of the interpretation of the Uniform Act by Brooks and Settle, and upon reconsideration of the Ehrenzweig article and the Commissioners' Notes to UNIFORM ACT $\S \S 13,14$, the author modifies the view on punitive decrees expressed in Bodenheimer, Rights of Children, supra note 21, at 503-04. If the decree is punitive in the narrow sense explained in the text, it falls under the equitable exenption from recognition under the Act.

169. This rule explains the result, although not the reasoning, in Wheeler v. District Court, 186 Colo. 218, 526 P.2d 658 (1974), the first Colorado Supreine Court case under the Uniform Act. The father had custody of three children under an Illinois decree. Four years later he inoved to Colorado. Although the Illinois court had granted permission for the inove, it changed its decree and gave custody to the mother shortly after the father's departure. This sudden inodification after the children had lived with the father for inore than 4 years seeins to have been precipitated by the father's change of dounicile. Under the punitive decree exception, Colorado was not bound to recognize the custody change. Cf. deHart v. Laynan, 536 P.2d 789 (Alas. 1975), aff'd on app. from remand, 560 P.2d 1206 (Alas. 1977) (non-recognition of Ohio custody change which was apparently precipitated by the mother's move to Alaska).

In Miller v. Superior Court, 69 Cal. App. 3d 191, 138 Cal. Rptr. 123 (2d Dist. 1977), hearing granted, No. 77-118 (Calif. July 18, 1977), a California appellate court referred to the punitive inodification exception with apparent agreement. Nevertheless, the majority opinion failed to classify a custody inodification made by a court of another country as a punitive decree although the facts closely resembled the facts in Brooks, which the court cited. Id. at $204 \mathrm{n} .4,138 \mathrm{Cal}$. Rptr. at 129. After a dispute between 


\section{Constitutional Objections to Punitive Custody Modifications}

A punitive custody change may violate the constitutional right to travel if it is the result of an express or inplied restriction confining the custodial parent to continued residence within one state or locality. ${ }^{170}$ In the past, this constitutional question has rarely, if ever, been addressed; thus, there has been no authoritative ruling on this point. ${ }^{171}$ Recently the issue was squarely presented in two cases. ${ }^{172}$ In the first case, the court evaded the issue, ${ }^{173}$ while in the second the court made short shrift of it, declaring that the mother's right to travel was not in fact impaired inasmuch as she remained "free to travel as she pleases without the children."174

Considering the great rise in the number of divorces, the increasmg mobility of former spouses seeking new lives for themselves, and the common phenomenon of children traveling by air or automobile to

the parents, the custodial mother in Miller had secretly removed the children from Sydney, Australia, to California where she had previously lived with the children for a number of years following her divorce. An Australian court thereupon changed custody to the father in ex parte proceedings. See note 154 supra. Without explanation, the majority declared that the foreign decree "was neither punitive nor unenforceable under California law." 69 Cal. App. 3d at 204, 206, 138 Cal. Rptr. at 130, 131. In a vigorous dissent Presiding Justice Roth took the position that the foreign decree was a punitive default judgment not entitled to recognition and enforcement. Id. at 225, 123 Cal. Rptr. at 143 .

170. See Comment, Restrictions on a Parent's Right to Travel in Child Custody Cases: Possible Constitutional Questions, 6 U. CAL. D.L. Rev. 181 (1973).

171. California courts have stated that an impairment of the father's right to visit the child does not justify restraint on the mother's free movement unless the child's welfare is detrimentally affected. See, e.g., Dozier v. Dozier, 167 Cal. App. 2d 714, 334 P.2d 957 (2d Dist. 1959); Ward v. Ward, 150 Cal. App. 2d 438, 309 P.2d 965 (3d Dist. 1957); Clark, Cases and Problems on Domestic Relations, supra note 30, at 87879.

172. Miller v. Superior Court, 69 Cal. App. 3d 191, 138 Cal. Rptr. 123 (2d Dist. 1977), hearing granted, No. 77-118 (Calif. July 18, 1977); Ryan v. Ryan, 219 N.W.2d 912 (Minn. 1974).

173. In Ryan, a mother contended that the Minnesota statute permitting custody reversals upon a change of residence (MINN. Stat. ANN. § 518.175(3), (4) (West 1976) ) is unconstitutional as an abridgement of her right to be free to travel uninhibited by rules that unreasonably burden her movement. The court accepted the Attorney General's argument that the sanctions imposed by the trial court are independent of the statute and held that "there is no constitutional issue before us." 219 N.W.2d at 917 .

174. Miller v. Superior Court, 69 Cal. App. 3d 191, 205, 138 Cal. Rptr. 123, 130 (2d Dist. 1977), hearing granted, No. 77-118 (Calif. July 18, 1977) (italics in original). On Miller, see notes 154 and 169 supra. With Miller, compare the following observations of a Texas court:

[T] extreme nature. It may drastically affect the freedom of decision of the custodian of the child .... And .... if request for removal ... is denied, it may materially restrict the right of a citizen (who would not move without her child) to change the place of his or her residence . . . ."

Ex parte Rhodes, 352 S.W.2d 249, 251 (Tex. 1962). 
visit noncustodial parents, it is a safe prophesy that the right-to-move issue in this context is a constitutional question whose time has come or is overdue. Impediments on changes of residence held unconstitutional in recent United States Supreme Court cases ${ }^{175}$ are minimal in comparison with the restraints placed on parents in cases like Fritschler. ${ }^{170}$ Imposing the condition of leaving the children behind places the most direct and oppressive burden on the exercise of the constitutional freedom one can imagine. It is difficult to refrain froin predicting that, once this issue is fully aired, the right of custodial parents to move with the children will be upheld. ${ }^{177}$

Punitive custody changes are not only of questionable constitutionality and undeserving of enforcement by other states; they also are generally ineffective, and, what is worse, often cause the very evils the Uniform Act intends to remedy. Freedom to move has become an expectation common to all segments of society; consequently, a great inany parents disobey restraints on moving and punitive deprivations of custody. Apprehensive of possible sanctions, including seizure of the children by police, parents leave in secret and conceal their whereabouts. As has been noted, predeparture rearrangements of visiting schedules, aided by court counseling, would in many cases prevent such occurrences. ${ }^{178}$ An elimination of restraints on moving and of punitive custody changes by local courts would encourage such settlements and have a salutary effect on interstate custody law and the children involved. ${ }^{178}$

\section{B. Joint Custody}

Joint custody, sometimes referred to as divided custody, gives both parents legal responsibility for the child's care and alternating companionship of the child. ${ }^{180}$ The concept is not new, but in the past

175. Most of the recent cases involved the imposition of waiting periods on nonresidents as prerequisites for the exercise of certain rights. See, e.g., Dunn v. Blumstein, 405 U.S. 330 (1972); Shapiro v. Thompson, 394 U.S. 618 (1969). Cf. In re King, 3 Cal. 3d 226, 484 P.2d 983 (1969) (more severe punishment imposed for non-support on a non-resident than on a resident father "violates the individual's constitutional right to choose his own domicile and to travel freely throughout the country").

176. See note 148 supra and accompanying text.

177. Interstate visitation requirements may, of course, be imposed. See, e.g., D'Onofrio v. D'Onofrio, 144 N.J. Super. 200, 365 A.2d 27 (Ch. Div.), aff'd per curiam, 144 N.J. Super 352, 365 A.2d 716 (App. Div. 1976).

178. See note 120 supra.

179. This would not exclude temporary restrictions to prevent a parent from leaving the jurisdiction while a custody determination is in progress. The parent's presence with the child at a custody hearing is desirable, and is required or encouraged by various provisions of the Act. See UNIForm ACT $\$ \S 11,19,20$, CAL. Crv. CODE $\$ \S 5160,5168$, 5169. See also Bodenheimer, Legislative Remedy, supra note 21, at 1234-35.

180. See Fain, Custody, supra note 21, at 564-65; Note, Divided Custody of Chil- 
an award of joint custody was often a matter of form rather than substance; it was often combined with an award of physical custody to one of the parents so that actual custody was in fact lodged in one parent. ${ }^{181}$ In the past, courts have generally resisted true joint custody arrangements, in which both parents actually have equal responsibility and alternatimg companionship and control of the child, finding such plans detrimental to the child's interests. ${ }^{182}$ Today courts are under increassing pressure to recognize parental equality by permitting joint legal and physical custody, ${ }^{183}$ and they are awarding joimt custody in a somewhat larger number of cases. Such an award is most likely when both parents join in presentimg a plan of cooperative parenthood, ${ }^{184}$ but joint custody has occasionally been won in adversary contests. ${ }^{185}$ Professional and popular opimion on the desirability of joint custody is divided, but most psychiatrists and many family law practitioners seem to oppose it. ${ }^{186}$ Unquestionably, some exceptionally mature parents are able, through a great deal of effort, self-discipline and emotional control, to

dren after Their Parents' Divorce, 8 J. FAM. L. 58 (1968); Note, The California Custody Decree, 13 STAN. L. REV. 108, 112 (1960).

181. See Gudelj v. Gudelj, 41 Cal. 2d 202, 259 P.2d 653 (1953); Fain, Custody, supra note 21, at 564. Courts are inclined in such cases to consider the parent who has physical custody as the true custodian of the child. See Burge v. City \& County of San Francisco, 41 Cal. 2d 608, 262 P.2d 6 (1953); Storrs v. Van Anda, 62 Cal. App. 3d 189, 132 Cal. Rptr. 878 (2d Dist. 1976).

182. McFadden v. McFadden, 206 Or. 253, 292 P.2d 795 (1956); Martin v. Martin, 132 S.W.2d 426 (Tex. Ct. App. 1939); CLARK, supra note 21, at 590; Mnookin, supra note 30 , at 233 .

183. E.g., Quinn, Fathers Cry for Custody, JuRIs Doctor 42 (May 1976). Legislatures are under similar pressure. A.B. No. 3475, which was introduced in the California legislature in the 1975-76 session, would have amended section 4600 of the Civil Code to make specific provision for joint legal and physical custody under certain conditions.

184. See, e.g., Schilleman v. Schilleman, 61 Mich. App. 446, 232 N.W.2d 737 (1975) (parents take turns living in the matrimonial home where the children remain); Holly, Joint Custody: The New Haven Plan, MS., Sept. 1976, at 70-71 thereinafter cited as Holly].

185. See, e.g., DeForest v. DeForest, 228 N.W.2d 919 (N.D. 1975); Quinn, supra note 183 , at 46 .

186. See, e.g., Ponder v. Rice, 479 S.W.2d 90 (Tex. Ct. App. 1972) (opposed); Baum, The Best of Both Parents, N.Y. Times, Oct. 31, 1976, \& 6 (Magazine), at 45 [hereinafter cited as Baum]; Controversial Custody Idea, 1 FAM. L. REP. (BNA) 2708 (Report on A.B.A. Family Law Section meeting, Aug. 11-13 (1975)); Dullea, Joint Custody: Is Sharing the Child a Dangerous Idea?, N.Y. Times, May 24, 1976, at 24; Plant, The Psychiatrist Views Children of Divorced Parents, 10 L. \& CoNTEMP. Prop. 807,812 (1944) ("It remained to modern Solomons to be the ones to really cut the child in two").

German psychiatrist Reinhart Lempp writes that parents, when making a seemingly equitable arrangement on custody, unconsciously seek to delude the child into believing that no divorce occurred: "that the child still belongs so-to-speak to both parents in equal shares. This is an illusion and a false pretense which seldom ends well." $R$. LEMPP, DIE EHESCHEIDUNG UND DAS KIND 37 (1976) (translation by the author). 
handle a joint custody arrangement. ${ }^{187}$ The effect upon the children, however, is not at all clear.

Although joimt custody awards probably make up a relatively small percentage of all custody decisions at the present time, ${ }^{188}$ they present substantial problems for interstate enforcement. Joint custody decrees normally provide that the child's time will be divided between the parents at rather brief intervals. Thus, one basic prerequisite is geographical closeness. ${ }^{189}$ A joint custody arrangement cannot operate in two distant states. If one of the parents moves and the other seeks to enforce the decree in another state, it will be impossible for that state to comply with the Uniform Act's enforcement provisions. In the interstate context, joint custody is simply undetermined custody. ${ }^{190}$

Local courts faced with a request for joint custody should seriously consider the interstate consequences of a joint award. If both parents seriously desire co-custody, the court should inquire into their plans for the future and what thought they have given to custody arrangements should one or both leave the state. Every joint custody decree exposes the child to the very real risk that the parents will subsequently separate geographically. Thus the joint decree may have done nothing but postpone the day of reckoming, a day which means a new crisis for all concerned and may bring more turmoil and more suffering upon the child than the divorce itself. ${ }^{191}$

If joint custody is nevertheless granted after weighing these risks, all possible steps should be taken at the time of the decree to impress upon the parents the necessity of making new custody arrangements before either of them leaves the state. A statement that the parents have been advised of this need inght be included in the decree. Re-

187. Published testimonials by "Tuesday-Thursday-Saturday" parents indicate that joint custody can work for some parents. See, e.g., Baum, supra note 186, Holly, supra note 184.

188. Statistics are not available. The contemporary type of joint custody based on agreement is probably limited to a small group of highly sophisticated couples who frequently are both professionals. See Baum, supra note 186, at 45; Holly, supra note 184, at 71 .

189. See Holly, supra note 184, at 71.

190. If one parent remains in the state where the original decree was granted, it will be up to that state, which has continuing jurisdiction, to determine the child's custodian. Under some circumstances jurisdiction would be declined under the inconvenient forum rule. See text accompanying notes 108-116, supra.

191. In Alameda County, California, when a judge refers a proposed joint custody plan to the conciliation court for an evaluation, if the plan is found workable at all, the counselor will not recommend it to the court unless the parties agree who is to have physical custody. Interview with Elizabeth O'Neill, Supervising Counselor, Alameda County Conciliation Court (March 24, 1977). If courts would follow this policy, the interstate problem of joint custody would be alleviated. See note 18 supra and accoinpanying text. 
straints on moving from the jurisdiction should not be included, however. As has been pointed out, such restrictions often have the undesirable effect of encouraging a parent who desires to leave to do so in secret, without making new custody arrangements. ${ }^{102}$

If a custodial partnership must be dissolved and the parents cannot agree on a new custody arrangement, careful judicial handling is required. Certainly one party's imtention to move or accomplished change of residence is not a "fault" that is relevant to the new custody determination. ${ }^{103}$ Where court counsehing services are available, a judge would want to turn to them for assistance. ${ }^{104}$ An adversary hearing should be the recourse of very last resort. In some cases, it may be easy to transform joint custody into primary custody with visitation rights; the custody partnership may have dissolved in the course of time and events, as the child in fact lives primarily with one parent. The child would then remain with the parent who has become the de facto custodian, whether or not that parent moves.

\section{Excessive Custody Modifications}

In many states the courts have virtually unlimited discretion to modify their own custody decrees. ${ }^{195}$ The factors that may produce an order moving a child from one parental home to the other are as manifold and as unpredictable as those relied on in making an initial decree. ${ }^{196}$ A child may be moved because of an improvement in the living conditions of the noncustodial parent, because of a parent's remarriage, or because of the parent's recovery from a physical or mental illness. Proof of a change of circumstances is not necessarily required, however. ${ }^{107}$ Some courts will change custody if they disapprove of the sexual morality or lifestyle of the custodial parent, or if one parent at-

192. See notes 178 and 179 supra and accompanying text.

193. See, e.g., UNIFORM MARRIAGE AND DivORCE ACT $\S 402$ : "The court shall not consider conduct of a proposed custodian that does not affect his relationship with the child." See also text accompanying notes 72-80, supra. Courts that consider a change of residence a ground for awarding custody to the other parent encourage extra-legal flights from the jurisdiction. See text accompanying notes 148-155, supra.

194. See, e.g., Elkin, Post-Divorce Counseling in a Conciliation Court, 1 J. DrvORCE - (1977); Marschall \& Gatz, The Custody Decision Process: Toward New Roles for Parents and the State, 7 N.C. CENT. L. J. 50, 62-65 (1975) (proposes court custody mediation).

195. See, e.g., ClARK, supra note 21, at 598-601; Freed \& Foster, The Shuffled Child and the Divorce Court, Trial 26, 34 (May/June 1974) ("It has been asserted that a third of all divorces involving children are followed by further litigation regarding them, and if such is the case, obviously the law with regard to modification is largely responsible").

196. See CIARK, supra note 21 , at 600 .

197. Id. See also, e.g., Simons v. Simons, 3 FAM. L. REP. (BNA) 2288 (Conn. Feb. 8, 1977). 
tempts to alienate the child from the other. ${ }^{198}$ The power to modify exists whether the original decree was based on parental agreement or was arrived at upon a court hearing. ${ }^{199}$

In recent years, psychiatric $^{200}$ and legal ${ }^{201}$ opinion stressing a child's need for stability and continuity has become the accepted policy of an increasing number of courts. A trend toward narrowing the discretion to modify custody decrees is clearly discernable. ${ }^{202}$ Several states have adopted the provision of the Uniform Marriage and Divorce Act that prohibits a change in custody unless the child is endangered in the existing environment and the advantages of the change outweigh the harm that may be caused by uprooting the child. ${ }^{203}$ Other states have adopted a similar judicial pohcy strongly favorimg the custodial status quo. ${ }^{201}$

As long as some states persist in allowing frequent modification of local custody decrees, however, other states, especially those which restrict modifications, may be reluctant to honor out-of-state modifications that they consider unnecessary or undesirable. Nonetheless, the problein of excessive modifications in the interstate sphere cannot be solved by a relaxation of the Uniform Act's requirement that the decrees be accorded full recogmition, regardless of the second court's dissatisfaction with the judgment. The temptation might arise to find an implied exception in the Act for decrees that have been modified without good reason. It would be argued that, as in the case of punitive custody decrees, such unnecessary or unreasonable modifications are not based upon considerations of the best interests of the child and are therefore not entitled to that degree of respect that custody decrees generally deserve. ${ }^{205}$

This approach would have the most unfortunate result of putting the trial court in the second forum in the position of an appellate court

198. See Clark, supra note 21 , at 584-90, 600-01.

199. Id. at 598.

200. E.g., J. Goldstein, A. FreUd, \& A. Solnit, supra note 29; Watson, The Children of Armageddon: Problems of Custody Following Divorce, 21 SYRAcuse $L$. REv. 55 (1969).

201. 2 ARMSTRONG, supra note 1, at 306 (Supp. 1966); see also CLARK, supra note 21 , at 326,600 .

202. See Bodenheimer, Rights of Children, supra note 21, at 498-99.

203. UNIFORM MARRIAGE AND DIVORCE ACT $\$ 409$. This section has been adopted by Colorado, Colo. Rev. Stat. $\$ 14-2-11$ (1973), Montana, Mont. Rev. Codes AnN. $\S 48-312$ (Supp. 1975), and Washington, WASH. REV. CODE $\$ 26.09 .26$ (1977).

204. See, e.g., Nichols v. Nichols, 516 P.2d 732 (Alas. 1973); Warren v. Warren, 19 Or. App. 671, 528 P.2d 1088 (1974); Laughton v. Laughton, 71 Wyo. 506, 259 P.2d 1093 (1953). See also Forde v. Sommers, 3 FAM. L. REP. (BNA) 3113 (N.H. Supreme Ct. Apr. 29, 1977).

205. See text accompanying notes 160-169, supra. 
for the first forum, judging the first forum's actions to determine whether they constituted an abuse of discretion. This setting of one jurisdiction against another, when there is no reason to believe that one judge is in fact a better guardian of the child's best interests than another, ${ }^{206}$ is precisely what the Act was designed to avoid. Allowing the second court to assume jurisdiction in the case of punitive decrees is a narrow and administrable exception to the general principle of the Act. Beyond that, any relaxation of the recognition primciple creates the risk of losing the principle itself. ${ }^{207}$

The remedy lies in the hands of the local courts and the state legislatures. Adoption of the restrictive modification section of the Uniform Marriage and Divorce Act ${ }^{208}$ would be the best solution. Another approacli would be an acceleration of the present trend in local judicial policies that disapproves of excessive custody modifications.

\section{CONCLUSTON}

Initial experience with the operation of the Uniform Child Custody Jurisdiction Act has on the whole been positive and promising. Out-of-state custody decrees are being honored, and kidnapped and detained children are being returned. The Act is beginning to have a deterrent effect on child snatching.

As more states join in adopting the Act, the chances are good that interstate custody law will continue to progress from the chaotic conditions that still prevail in many jurisdictions toward a substantial degree of unanimity and harmony.

Interstate custody law is, however, intimately connected with and dependent upon custody decisionmaking in the courts of the individual states, and certain local practices liamper effective interstate procedures. It is hoped that growing familiarity with the legal changes on the interstate scene will lead local courts to adopt a transstate point of view. Geographic separation of menibers of severed families is a contemporary phenomenon that can no longer be ignored or prevented.

206. See notes 29-30 supra, and accompanying text.

207. For discussion of this point, see Foster \& Freed, supra note 121, at 1025-26.

208. See note 203 supra. 